\title{
Targeting Mononuclear Phagocyte Receptors in Cancer Immunotherapy: New Perspectives of the Triggering Receptor Expressed on Myeloid Cells (TREM-1)
}

\author{
Federica Raggi $(1)$ and Maria Carla Bosco * $*$ \\ Laboratory of Molecular Biology, IRCCS Istituto Giannina Gaslini, 16147 Genova, Italy; federicaraggi@gaslini.org \\ * Correspondence: mariacarlabosco@gaslini.org
}

Received: 21 April 2020; Accepted: 22 May 2020; Published: 23 May 2020

\begin{abstract}
Inflammatory cells are major players in the onset of cancer. The degree of inflammation and type of inflammatory cells in the tumor microenvironment (TME) are responsible for tilting the balance between tumor progression and regression. Cancer-related inflammation has also been shown to influence the efficacy of conventional therapy. Mononuclear phagocytes (MPs) represent a major component of the inflammatory circuit that promotes tumor progression. Despite their potential to activate immunosurveillance and exert anti-tumor responses, MPs are subverted by the tumor to support its growth, immune evasion, and spread. MP responses in the TME are dictated by a network of stimuli integrated through the cross-talk between activatory and inhibitory receptors. Alterations in receptor expression/signaling can create excessive inflammation and, when chronic, promote tumorigenesis. Research advances have led to the development of new therapeutic strategies aimed at receptor targeting to induce a tumor-infiltrating MP switch from a cancer-supportive toward an anti-tumor phenotype, demonstrating efficacy in different human cancers. This review provides an overview of the role of MP receptors in inflammation-mediated carcinogenesis and discusses the most recent updates regarding their targeting for immunotherapeutic purposes. We focus in particular on the TREM-1 receptor, a major amplifier of MP inflammatory responses, highlighting its relevance in the development and progression of several types of inflammation-associated malignancies and the promises of its inhibition for cancer immunotherapy.
\end{abstract}

Keywords: mononuclear phagocytes; tumor-associated macrophages and dendritic cells; tumor microenvironment; cancer immunotherapy; pattern recognition and immunoregulatory receptors; triggering receptor expressed on myeloid cells

\section{Introduction}

The onset of cancer involves a complex interplay among neoplastic, stromal, endothelial, and infiltrating inflammatory cells, which results in the establishment of a highly specialized tumor microenvironment (TME) [1]. Clinical and experimental evidence indicate that chronic inflammation is an indispensable participant in the neoplastic process, fostering genomic instability, epigenetic modifications, angiogenesis, cancer cell proliferation, survival, and dissemination [2-7]. Indeed, many cancers arise at sites of infection and chronic inflammation, and different inflammatory conditions, e.g., inflammatory bowel diseases (IBD), are highly correlated with the increased risk of neoplastic transformation [1,8-10]. Furthermore, cancer-related inflammation negatively affects the clinical efficacy of conventional therapies (chemotherapy and radiotherapy) and immunotherapy, antagonizing or hindering therapeutic responses $[5,11]$. 
The type of inflammatory cells present at tumor sites is responsible for tilting the balance between tumor progression and regression [1,3,5,12-17]. In particular, mononuclear phagocytes (MPs) have been recognized as major components of the inflammatory infiltrate in most solid human malignancies and crucial drivers of cancer-associated inflammation, being involved in every step of tumorigenesis from early transformation through to metastatic progression [3-5,18-23]. They are highly versatile immune cells able to adapt to different environmental conditions and display distinct phenotypes and functional programs dictated by a network of signals, including cytokines, microbial pathogens (pathogen-associated molecular patterns, PAMPs), molecules released by damaged/stressed cells (damage-associated molecular patterns, DAMPs), and metabolites [24-33]. Environmental stimuli are integrated through the cross-talk between multiple activatory/inhibitory receptor families, whose dynamic equilibria finely tune MP responses in diseased tissues, regulating their inflammatory and effector functions [34]. Alterations in receptor expression/activation can create excessive inflammation and, when chronic, promote tumorigenesis [33,35-39]. Given their role in carcinogenesis and influence on the effectiveness of anti-tumor therapies, MPs have attracted a lot of interest as potential targets of immunotherapeutic strategies, a concept that has already been investigated in several tumors $[4,11,40-43]$.

In this review, we provide a comprehensive overview of published studies on MP physiopathology in the TME and an update of the state of the art of MP-targeted immunotherapeutic approaches. We summarize the current knowledge on the role of MP receptors in inflammation-mediated carcinogenesis and discuss the most recent advances regarding the attempts to their therapeutic targeting. We focus in particular on the triggering receptor expressed on myeloid cells (TREM1)-1, a major player in the amplification of MP inflammatory responses [44,45], highlighting its relevance in the development of several inflammation-associated malignancies and the promises of its inhibition as a novel therapeutic strategy in cancer.

\section{MPs in Tumors}

\subsection{MP Pro- and Anti-Cancer Activities}

MPs are recruited from the circulation to tumor sites by tumor-derived factors as primary monocytes $(\mathrm{Mn})$, differentiating into tumor-associated macrophages (TAMs) or dendritic cells (TADCs) [4,18-20,46-52].

Macrophages are a heterogeneous cell population and a key component of innate defense mechanisms, exerting microbicidal and immunostimulatory activities. In the TME, TAMs display a dual influence on tumor progression $[23,40,53,54]$. They have the potential to activate immunosurveillance and exert anti-tumor responses by destroying cancer cells or inhibiting their proliferation through the release of cytokines, reactive oxygen species (ROS), and nitric oxide (NO), complement components, and prostaglandins. However, they can be subverted by the tumor to support its progression, spread, and immune evasion through the production of pro-angiogenic, mitogenic, metastatic factors, and immunosuppressive cytokines and the upregulation of inhibitory receptors $[11,21,22,40,50,53,55,56]$. Preclinical and clinical studies demonstrated that the nature of the activating stimulus and the combination of different stimuli in the TME can profoundly impact upon the type of response that occurs, polarizing TAMs into specialized functional subsets $[24,26,30]$. In addition, TAMs can undergo a rapid and reversible shift among functional programs in response to changes in the activating stimulus, often exhibiting mixed phenotypes [21,24,57-60]. It is currently accepted that TAMs involved in the early tumor initiation process display a "M1-like" pro-inflammatory and tumoricidal phenotype, activating Th1-type immune responses and eliminating transformed cells, but, as the tumor grows, they are educated by the TME to switch to an "M2-like" immunosuppressive and tumor-promoting phenotype, fostering tumor growth/metastatization and immune evasion [3,4,11,20,24,30,40,47,57-59,61,62]. High TAM infiltration in solid tumors is generally associated with poor prognosis and reduced overall survival 
in both experimental models and neoplastic patients [3,10,47,50,56,63-67], although a correlation with better prognosis has been suggested for some tumors [68].

DCs are professional antigen-presenting cells central to the orchestration of innate and acquired immunity and the maintenance of self-tolerance [51]. Deregulated DC responses may result in the amplification of inflammation, loss of tolerance, or establishment of immune escape mechanisms [25,33,69-71]. TADCs were described in the TME of many cancer types, and their inactivation was reported as one of the main mechanisms of tumor escape [72]. Several evidence suggest that TADCs can exist in a multitude of functional states during the course of the disease [46,71,73], and that their immunogenic capacity may be strongly conditioned by the TME, ranging from immunostimulatory to immunosuppressive [74,75]. In established tumors, TADCs display mostly an immature phenotype, characterized by a low expression of T-cell costimulatory and high levels of inhibitory molecules, defective migration to lymph nodes, and tolerance to tumor antigens, promoting tumor progression, dissemination, and immune evasion $[46,48,73,74,76]$. However, TADCs can generate tumor-specific adaptive immune responses, a capacity that is enhanced via DC-targeted vaccines $[70,71,77]$.

\subsection{Tumor Hypoxia Contributes to MP Pro-Tumoral Phenotype}

A critical hallmark of the TME, especially in advanced-stage tumors, is represented by low partial oxygen tension $\left(\mathrm{pO}_{2}, 0-20 \mathrm{~mm} \cdot \mathrm{Hg}\right)$, referred to as hypoxia, which arises as a result of a disorganized or dysfunctional vascular network and poor $\mathrm{O}_{2}$ supply [78-80]. Hypoxia is an important driver of malignant progression, metastatic spread, and resistance to therapies and an indicator of poor prognosis in almost all solid tumors [13,78,81-83]. As documented by an extensive literature, hypoxia in the TME exerts multifaceted effects on every tumor component, influencing the nature and function of the inflammatory cell infiltrate and contributing to the establishment of immune resistance and tumor escape mechanisms [13,19,78-80,84-91].

Hypoxia is one of the critical signals regulating MP migration into tumors and conditioning the balance between their anti-/pro-tumoral functions [18,19,25,87,92-94]. Under hypoxic conditions, MPs are functionally reprogrammed through the differential expression of genes implicated in inflammation, angiogenesis, tissue disruption, mitogenesis, and immunoregulation $[19,25,79,85,92,93,95]$. Recent results point to the hypoxic environment as a direct trigger of human macrophage polarization towards a pro-tumoral "M2-like" state [31], confirming and extending studies in rodent tumor models showing that the intra-tumor $\mathrm{O}_{2}$ gradient is a critical regulator of the M1- to M2-skewed transition [61,93,96-98]. The correlation among the extent of M2-polarized TAM infiltration in hypoxic areas, tumor progression, and poor patient prognosis supports the hypothesis that reduced oxygenation contributes to MP acquisition of a pro-tumoral state [19,97]. Elucidation of the mechanisms underlying TAM/TADC dysregulated functions within the hypoxic TME may have important implications for their therapeutic reprogramming in tumors (see Section 2.3 for details).

\subsection{Targeting MPs in Cancers}

Considerable efforts from several research groups have been dedicated to the development of anti-tumor immunotherapeutic strategies targeting MP recruitment to, and/or survival and functional polarization in, tumors $[4,22,40,41,43,50,62,99]$. Many studies have been carried out in experimental animal models, and a few drugs are currently under clinical trial investigation both as monotherapies or in combination with standard therapies $[4,40]$.

The use of bisphosphonates encapsulated in liposomes or PEGylated nanoparticles to selectively deplete TAMs, owing to their phagocytic activities, showed promising anti-tumor effects in preclinical studies, reducing tumor burden, angiogenesis, and metastases. These agents are currently undergoing clinical trials as neoadjuvants in combination with chemotherapy and hormonal therapy $[4,10,22$, 40,50]. Targeting the CSF1/CSF1R pathway, which is critical for Mn/macrophage survival and differentiation toward a M2 phenotype, with mAbs and small molecule inhibitors was used as an 
approach to neutralize immunosuppressive M2-like TAMs in tumors or induce their reprogramming toward a M1 phenotype and is being studied in phase I/II clinical trials. Several CSFR1 inhibitors demonstrated some anti-tumor response and reduction in tumor cell invasion, in particular, in combination regimens with conventional therapy or T cell-directed immunotherapy $[4,10,11,22,40,43]$. TAM accumulation in the tumor can be mediated by Mn recruitment through the CCL2-CCR2 axis, and CCL2 inhibition by specific Abs correlated with reduced TAM infiltration, tumor growth, and metastasis in various experimental models, alone or in association with chemotherapies, suggesting the efficacy of this approach $[40,100,101]$. Various CCL2-neutralizing Abs and a CCR2 inhibitor are now being tested in clinical trials, showing promises results $[11,40,43,102,103]$. TAM re-education from a pro-tumoral toward a pro- inflammatory/tumoricidal state was also proposed as a therapeutic strategy, eliminating the drawbacks and long-term toxicity of macrophage ablation. Immune checkpoint and/or anti-immunosuppressive cytokine inhibitors are currently being tested at both preclinical and clinical levels to boost TAM phagocytosis and effector functions or inhibit their immunosuppressive activity. Clinical trials combining anti-TAMs agents (such anti-CSF1R Abs) and immune checkpoint inhibitors are ongoing in different solid tumor contexts $[4,43,104,105]$ (see Section 3.3 for details).

Promising developments in cancer-therapeutic strategies have also been made by targeting TADCs [72,106]. DCs have been used in vaccine preclinical models, and several phase I, II, and III clinical trials have tested the use of autologous Mn-derived DCs pulsed with tumor antigens to trigger anti-tumor $\mathrm{T}$ cell responses, with some results obtained in melanoma and prostate cancer patients [70-72]. Furthermore, TADC depletion in mice bearing ovarian cancer by targeting specific markers was also shown to significantly delay tumor growth and enhance the effect of standard chemotherapies [75]. More recently, the manipulation of TADCs to subdue their immunosuppressive functions and enhance their immune-stimulatory capacity has been carried out in preclinical studies, showing great promise $[3,71,72,106,107]$ (see Section 3.3 for details).

Encouraging results obtained in preclinical studies and early clinical trials across various therapeutic modalities and tumor types highlight the possibility of translating MP-targeted immunotherapeutic strategies to the clinical practice to complement and improve the efficacy of current anti-cancer therapies $[10,11,40,43]$.

\section{MP Activatory/Inhibitory Surface Receptors}

\subsection{Pattern Recognition Receptor (PRR) and Immunoregulatory Signaling (IRS) Receptors Expressed on MPS}

Knowledge of the receptors regulating MP responses has largely increased in the past two decades [33-36,38,71-73,92,108-115]. The deregulated expression of various members of the scavenger/ pattern recognition receptor (PRRs) and the inhibitory/activatory immunoregulatory signaling (IRS) receptor families in MPs has been reported to lead to aberrant inflammatory responses and trigger inflammatory diseases and inflammation-associated cancer development [71-73]. PRRs play a central role in the detection of and responses to PAMPs/DAMPs, triggering MP activation, immunogenicity, and pro-/anti-inflammatory and effector functions, which eventually result in pathogen clearance and tissue repair $[33,38,39,71,114,116-120]$. IRS receptors are involved in the pathogenesis of chronic inflammatory, allergic, and autoimmune diseases [34,35,92,108,112,120,121]. Their ligation can have both pro-inflammatory and immunoregulatory consequences by modulating differentiation/maturation, pro-/anti-inflammatory mediator secretion, phagocytosis, immune complex clearance, Ab-dependent cytotoxicity (ADCC), respiratory burst, and T cell priming [35,36,71,108,112,113].

\subsection{Role of PRR and IRS Receptors in Tumors}

Recent studies have highlighted the role of PRRs in mediating MP pro-/anti-tumor activities (Figure 1). Among them, toll-like receptors (TLRs) have been implicated in the regulation of macrophage polarization towards either an inflammatory/anti-tumor or a pro-tumorigenic phenotype in different cancers $[4,99,122]$. The expression of the macrophage scavenger receptor 1 (MSR1) was suggested 
to label a subset of anti-tumor TAMs, being significantly correlated with the inhibition of tumor progression, lower clinical stage, recurrence-free survival, and good prognosis in prostate cancer patients [64]. On the contrary, the macrophage receptor with collagenous structure (MARCO) was found expressed on a subtype of TAMs with an M2-like immunosuppressive phenotype in patients with mammary carcinoma, metastatic melanoma, and non-small cell lung cancer (NSCLC), and linked to poor prognosis $[123,124]$.

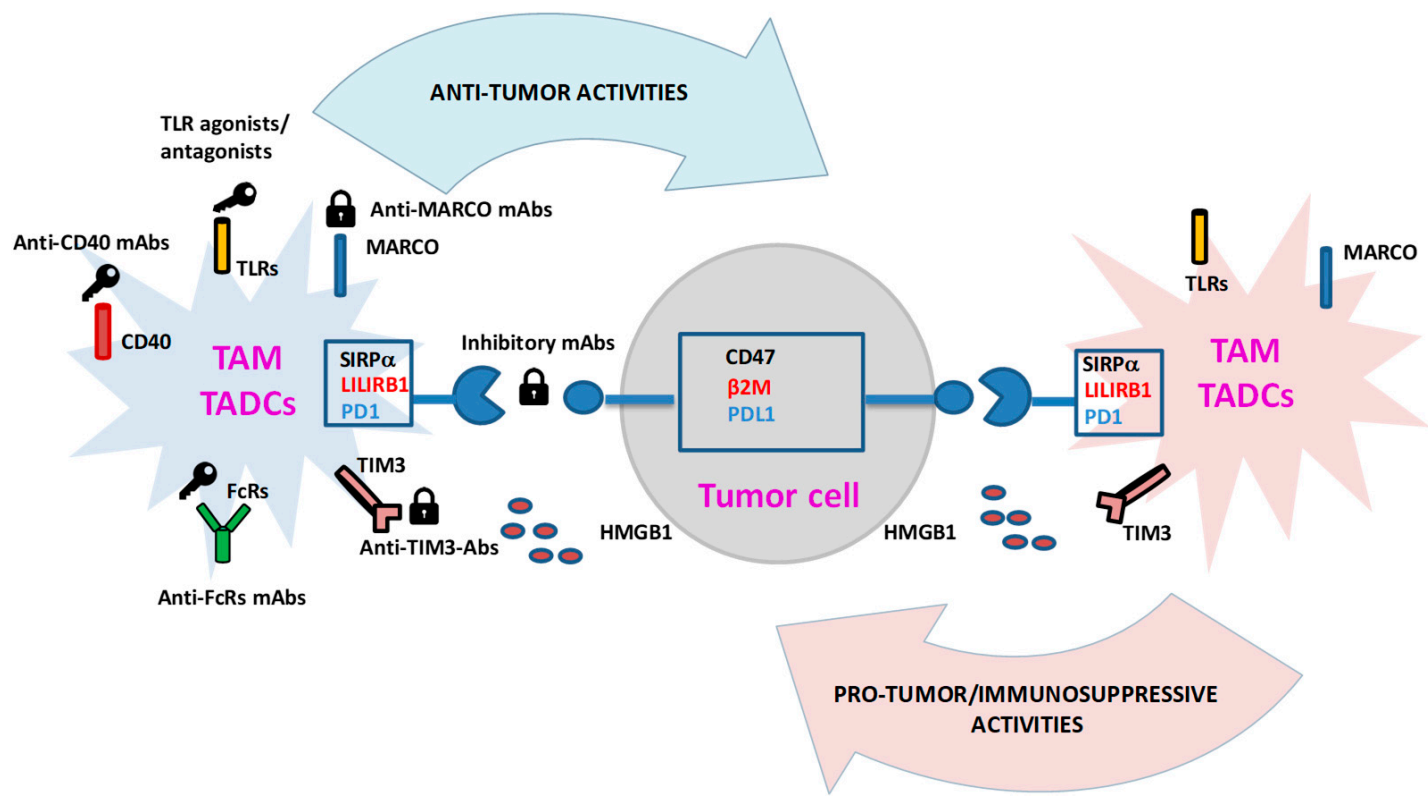

Figure 1. Schematic representation of pattern recognition receptor (PRR) and immunoregulatory signaling (IRS) receptors mediating mononuclear phagocytes (MP) pro-/anti-tumor activities and representing potential targets of cancer immunotherapy. The figure depicts a selection of MP receptors tested as potential immunotherapeutic targets in cancer. Targeting toll-like receptors (TLRs), $\mathrm{CD} 40$, Fc region of Igs (FcRs) activating receptors with agonist, or antagonist mAbs/ligands boosts tumor-associated macrophages (TAM)/tumor-associated dendritic cells (TADC) tumoricidal activities and $\mathrm{T}$ cell activation, enhancing their cytotoxicity, cancer cell phagocytosis, and/or antigen-presenting ability. Blockade of SIRP $\alpha$ LILRB1, PD-1 immunocheckpoint molecules, or macrophage receptor with collagenous structure (MARCO) and T cell Ig and mucin domain 3 (TIM-3) immunosuppressive receptors with inhibitory $\mathrm{mAbs}$ induces MP reprogramming toward an anti-tumor/immune-promoting state, eliciting TAM phagocytic activity and tumor cell killing and improving TADC ability to stimulate $\mathrm{T}$ cells. Activating and inhibitory approaches are indicated in the figure by keys and padlocks, respectively. TLRs, toll-like receptors; CD40, cluster of differentiation 40; FcRs, receptors for the Fc region of immunoglobulins; SIRP $\alpha$, signal regulatory protein-alpha, CD47, cluster of differentiation 47; LILRB1, leukocyte immunoglobulin-like receptor B1; $\beta 2 \mathrm{M}, \beta 2$-microglobulin; PD-1, programmed cell death-1; PD-L1, PD-1 ligand; MARCO, macrophage receptor with collagenous structure; TIM-3, T cell Ig and mucin domain 3; HMGB1, high mobility group box 1.

Some IRS receptors have been shown to serve as immune checkpoints by inhibiting MP anti-tumor activation and favoring tumor immune escape $[4,125,126]$ (Figure 1). The inhibitory receptor, signal regulatory protein-alpha (SIRP $\alpha)$, negatively regulates macrophage and DC phagocytic activity by interacting with its cognate ligand cluster of differentiation 47 (CD47) overexpressed on many types of 
cancer cells, increasing tumor invasion and metastasis $[4,43,127]$. Programmed cell death-1 (PD-1), as well as its ligand, PD-L1, are expressed on M2-like TAMs and TADCs (in addition to T lymphocytes) and upregulated during disease progression in both mouse cancer models and primary human tumors, inhibiting TAM phagocytic activity against tumor cells and the TADC adaptive immune-activating potential [72,74,104,106,128]. Another important immune checkpoint is represented by leukocyte immunoglobulin-like receptor B1 (LILRB1), which suppresses TAM phagocytic functions through the engagement of the MHC class I component $\beta_{2}$-microglobulin $\left(\beta_{2} \mathrm{M}\right)$ on cancer cells. The T cell Ig and mucin domain 3 (TIM-3) was also identified as an immune checkpoint expressed on a subset of macrophages, Mn, and DCs [129]. Its upregulation on DCs by factors present in the TME seems to be an important mechanism by which TADCs are locked into an immune-suppressive phenotype, preventing the detection of tumor-derived danger signals through an interaction with the DAMP molecule, high mobility group box 1 (HMGB1), and leading to the release of immune-suppressive factors, with consequent attenuation of the therapeutic efficacy of DNA vaccination and chemotherapy in experimental tumor models [130].

Elucidation of the stimuli in the TME involved in receptor deregulation has been the focus of intense research with the purpose of identifying new potential therapeutic targets. Hypoxic conditions similar to those present at tumor sites were reported to finely tune the PRR/IRS receptor repertoire in human Mn, Mn-derived macrophages, and DCs, by exerting a specific regulatory control on the expression profile of genes coding for various members of both receptor families, thus affecting cell responses toward an anti-tumor or a tumor-promoting direction [92,109-111,131-134].

\subsection{PRR and IRS Receptors as Therapeutic Targets in Cancer}

Advances in understanding PRR/IRS receptor expression changes have led to promising developments in cancer-therapeutic strategies targeting TAM/TADCs to induce their switch from a tumor-supportive toward an anti-tumor phenotype (Figure 1).

New immunotherapeutic approaches aimed at boosting TAM phagocytosis and effector functions using $\mathrm{mAbs}$ to specific receptors are currently under investigation $[35,43,105]$. Several therapeutic $\mathrm{mAbs}$ used in the clinic involve effector macrophages expressing the receptors for the Fc region of Igs (FcRs) to induce Ab-dependent phagocytosis (ADP) or ADCC of cancer cells (for a review see Reference [43]). Macrophage repolarization towards a tumoricidal phenotype was also attempted by targeting the TNF receptor superfamily member, CD40, which is expressed on MPs and binds CD40L on T cells [135]. Treatment with agonist anti-CD40 mAbs induced TAM immunostimulatory and tumor inhibitory effects in mouse tumor models both alone and in combination with anti-CSF1R mAb, by enhancing antigen-presentation and pro-inflammatory cytokine production and priming naive $\mathrm{T}$ lymphocytes [136-139]. This observation opened the way for the development of clinically relevant anti-CD40 mAbs, which have been tested in clinical trials for advanced-stage pancreatic tumors alone or in combination with chemotherapy, leading to partial response $[4,43,140]$.

Another important example of Ab-based targeted therapy comes from studies of the CD47/SIRP $\alpha$ axis. Macrophages can be induced to phagocytize tumor cells by CD47/SIRP $\alpha$-blocking agents, resulting in antigen presentation and promotion of adaptive immune responses against tumors [127]. Blocking SIRP $\alpha$ also polarizes TAMs to an "M1-like" anti-tumor phenotype [99]. Therapeutics targeting the CD47/SIRP $\alpha$ axis demonstrated anti-tumor efficacy both in vitro and in vivo in preclinical models and are currently being evaluated in clinical trials for both solid and haematologic malignancies as single agents and as combination therapies with tumor-opsonizing mAbs [4,43,126,127,141-143]. Blockade of the $\beta 2 \mathrm{M} / \mathrm{LILRB} 1$ interaction was found to stimulate tumor cell phagocytosis by TAMs and significantly slow tumor growth in mice, representing an interesting anti-cancer immunotherapeutic approach [144]. Among the strategies aimed at TAM reprogramming, PD-1/PD-L1 targeting with specific mAbs was also shown to increase TAM phagocytosis, reduce tumor growth, and lengthen survival of tumor-bearing mice in a macrophage-dependent fashion [22,104,105]. Interestingly, high-dimensional profiling studies of immune cell populations infiltrating sarcomas of mice treated with anti-PD-1 mAbs, 
alone or in combination with anti-CTLA-4 mAbs, revealed Mn/macrophage remodeling in the tumor microenvironment, providing compelling support to the hypothesis that successful immune checkpoint therapy favors the generation of TAMs with an M1-like pro-inflammatory/anti-tumor phenotype while decreasing the induction of TAMs with an M2-like immunosuppressive phenotype [145]. Anti-MARCO mAbs similarly induced TAM re-education towards a pro-inflammatory phenotype in preclinical mouse models of breast and colon carcinoma and melanoma, resulting in increased tumor immunogenicity and tumor growth/metastasis inhibition, and improving the efficacy of checkpoint immunotherapy [123].

Another emerging approach to direct macrophage functions for cancer immunotherapy is to manipulate TLR signaling using synthetic ligands [99]. TLR3, TLR4, TLR7/8, and TLR9 agonists have been explored as vaccine adjuvants in different mouse cancer models, showing TAM repolarization toward an "M1 like" phenotype and improved tumoricidal activity both alone and in combination with immune-checkpoint inhibitors [146-149]. TLR7 and TLR9 agonists are currently being tested in clinical trials, resulting in tumor inhibition and increased lymphoid immune cell infiltration $[4,99,122]$. Anti-tumor properties of TLR2 and TLR4 antagonists or cognate ligands have also been observed [122].

TADC manipulation to rescue their immune stimulatory potential also represents an intriguing area of therapeutic impact $[71,72,106]$. Similarly to TAMs, TADCs are an important target of checkpoint inhibitor-based approaches, with promising results in preclinical studies. Blockade of the PD1/PD-L1 axis on murine TADCs improved their ability to stimulate $\mathrm{T}$ cell activation $[72,74,128]$. A recent study by Mayoux et al. [106] highlighted the strong correlation between a high DC gene signature and clinical response to treatment with an anti-PD-L1 $\mathrm{mAb}$ in patients with renal cell carcinoma and NSCLC. These investigators established the biological basis of PD-L1 blockade on TADCs, showing a disruption of the PD-L1/B7-1 interaction and CD28 costimulation by B7-1 on T cells, suggesting that anti-PD-L1 immunotherapy reinvigorates the TADC costimulatory function, enhancing $\mathrm{T}$ cell priming. TIM-3 targeting on TADCs by specific mAbs was also shown to delay tumor progression in a mouse model of lymphoma, although its efficacy is not completely clear and in part controversial due to the TIM-3 expression by multiple cell types with potentially different roles [129]. A number of anti-TIM3 mAbs are now being tested in early phase clinical trials as monotherapy or in combination with anti-PD-1/PD-L1 mAbs [150]. CD40 and TLR3 costimulation on TADCs was shown to increase their $\mathrm{T}$ cell immunostimulatory activity, inducing the rejection of ovarian carcinoma in a mouse model [151]. Recently, the combination of DC vaccines and checkpoint molecule inhibitors led to therapeutic responses in a phase II study in melanoma patients [3,72,107]. Furthermore, clinical use of TLR ligands as adjuvants for DCs vaccines against cancer has yielded promising results [72].

Taken together, these findings demonstrate that the use of Abs/ligands directed to specific MP receptors to shift their balance from a pro-tumorigenic/immunosuppressive toward an anti-tumoral phenotype represents an attractive alternative to classic tumor treatments, improving the efficacy of current immunotherapy in combinatorial strategies [22,105,122].

\section{TREM}

Novel IRS receptors have been recently described in MPs. Among them, the TREM receptor family belonging to the Ig-like superfamily has been reported to participate in innate immune responses and be implicated in several infectious and non-infectious inflammatory diseases, autoimmune disorders, and cancers [44,152-157]. Six trem genes (Trem1, Trem2, Treml1-4) have been identified clustered on human chromosome 6p21 [153,158] and mouse chromosome 17C3, with four of them encoding structurally related type I transmembrane glycoproteins bearing a single extracellular Ig-like ectodomain (TREM-1, TREM-2, TREML-3, and TREML-4) [157,159]. The TREM isoforms have a short cytoplasmic tail (CYT) without a signaling motif, pairing for signaling with the transmembrane adapter, DNA-activating protein 12 (DAP12), which carries an immune receptor tyrosine-based activatory signal-transducing motif (ITAM) [152]. Despite similar structure and sequence homology, TREM isoforms show different cell-type expression patterns and functional activities [44,154,160]. TREM-1 (CD354) is the first 
identified and best-characterized family member and an important regulator of myeloid cell immune responses [37,45,153,154,161,162].

\subsection{TREM-1 Structure and Expression Regulation in MPS}

Two forms of TREM-1 were identified: 1 ) a transmembrane glycoprotein ( $\approx 30-\mathrm{kDa})$, composed of a signal peptide, the extracellular Ig-like domain, a membrane spanning region, and a short CYT [45,154, 156,158,163-165]; 2) a soluble form (sTREM-1, $\approx 27 \mathrm{kDa}$ ), devoid of both transmembrane and cytoplasmic domains, either derived from alternative splicing of TREM-1 mRNA [153,155,166] or from shedding of the extracellular domain of the membrane-bound form by matrix metalloproteinase (MMP)-mediated proteolytic cleavage $[167,168]$. sTREM-1 acts as a decoy receptor, sequestering the TREM-1 ligand and preventing its binding to membrane-bound TREM-1 and receptor activation [162,169].

TREM-1 is developmentally regulated in MPs, being constitutively expressed in blood Mn and a subset of tissue macrophages [45,170] and downregulated upon Mn differentiation into DCs and Langerhans cells (LCs) [110,111,161,162,171-173]. Several stimuli can regulate TREM-1 expression (Figure 2). Increased TREM-1 surface levels and/or sTREM-1 release were demonstrated in vitro in both mouse and human Mn/macrophages in response to PRR activation by bacterial and viral PAMPs [37, 45,168,174-182] and bacteria challenge [45,162,183], and in vivo in animals [162,168,182,184-189] and patients [162,181,185,190-192] suffering from bacterial, fungal, and viral infections. In addition, pro $(\mathrm{TNF} \alpha)$ - and anti- (TGF- $\beta$, IL-10) inflammatory cytokines can increase and abrogate, respectively, TREM-1 expression [171,193]. Lipid mediators, such as prostaglandins, also modulate TREM-1 surface levels in both murine and human macrophages [194,195]. Expression regulation occurs mainly at the transcriptional level through the interaction of various transcription factors with specific sites in the TREM-1 promoter $[37,183,196-200]$.

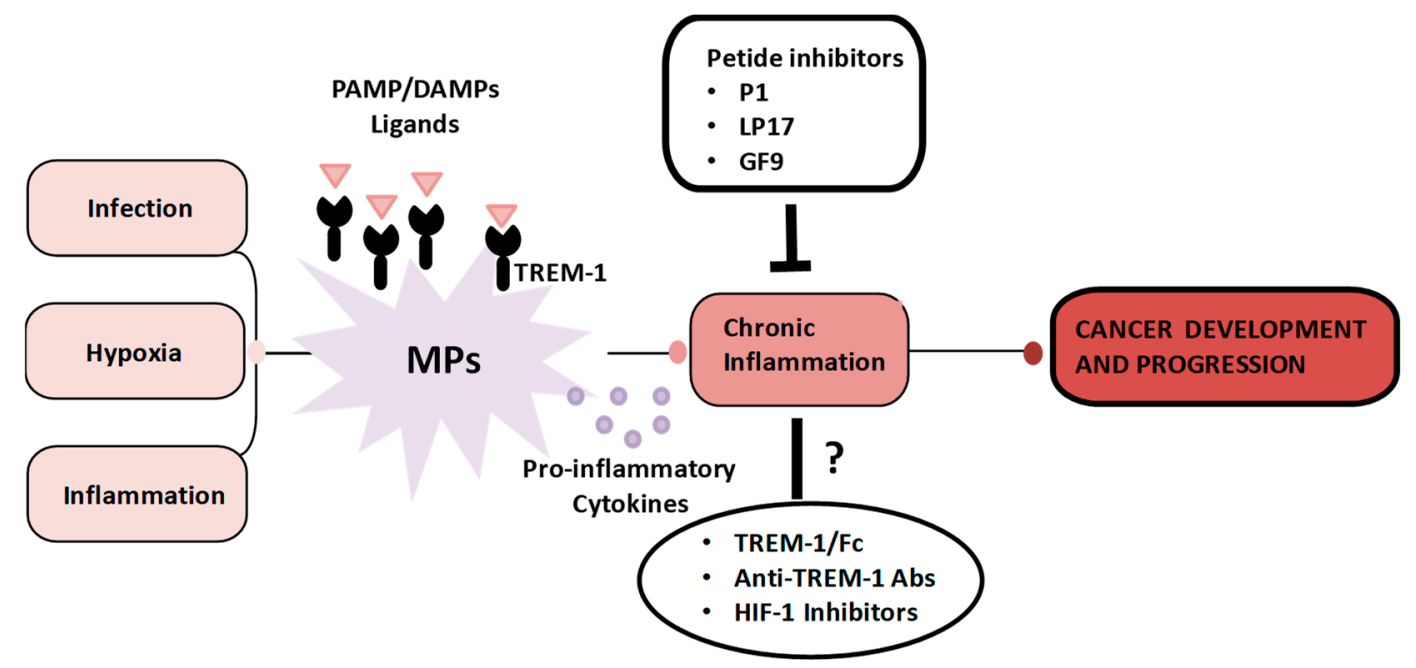

Figure 2. Role of TREM-1 expressed on MPs in chronic inflammation-associated carcinogenesis and potential as a new immunotherapeutic target in cancer. MPs are recruited to sites of inflammation, infection, and tumor growth, where they respond to microenvironmental stimuli, such as infectious/inflammatory agents and hypoxia, by upregulating TREM-1. TREM-1 engagement by specific pathogen-associated molecular pattern (PAMP)/damage-associated molecular pattern (DAMP) ligands present in the microenvironment promotes MP secretion of pro-inflammatory, chemotactic, angiogenic, and matrix-remodeling cytokines, resulting in the amplification of the ongoing inflammatory process and contributing to the development and progression of inflammation-associated malignancies. TREM-1 blockade by specific synthetic peptide inhibitors attenuates MP-mediated chronic inflammation and tumor progression in various preclinical mouse models, pointing to TREM- 1 as a novel attractive target for cancer immunotherapy. Alternative TREM-1 inhibitors, such as the TREM-1/Fc fusion protein, antagonist anti-TREM-1 mAbs, and anti-HIF inhibition are currently being tested. 
Interestingly, a major role for hypoxia as a TREM-1 trigger was demonstrated by Bosco and coworkers in distinct human MPs populations [31,109-111,201] (Figure 2). The TREM-1 transcript, membrane-bound protein, and sTREM-1 levels were significantly increased by hypoxia in primary Mn [109,202], Mn-derived macrophages [131], and upon M1/M2 polarization [31]. Furthermore, TREM-1 was induced ex novo on Mn-derived DCs [92,110,111] and LCs [201] generated under hypoxia, indicating that hypoxic stimulation can overcome TREM-1 developmental downregulation. A hypoxia response element (HRE) $[25,78,203]$ was identified in the human TREM-1 gene promoter [110,111], and the hypoxia-inducible transcription factor (HIF)-1, the master regulator of cell response to hypoxia and an important activator of innate immune cells [204], was shown to be involved in TREM-1 inducibility by hypoxia $[110,111]$. TREM-1 expression was confirmed in vivo in macrophages, DCs, and LCs infiltrating hypoxic inflammatory tissues $[31,110,201]$ and in TAMs infiltrating HIF-1+ glioblastoma and hepatocellular carcinoma (HCC) [202,205] (see Section 6 for details), suggesting the potential relevance of this molecule as a regulator of MP functions under hypoxic conditions.

\subsection{TREM-1 Putative Ligands and Signaling}

The identification of the TREM-1 ligand remains controversial. A broad range of molecules have been proposed as putative TREM-1 ligands [37]. Studies with a recombinant TREM-1/Fc fusion protein, consisting of the human TREM-1 extracellular domain fused to the Fc portion of Igs, and anti-TREM-1 mAbs suggested the presence of a soluble ligand in the serum of septic patients or a membrane-bound ligand on the surface of human platelets, respectively $[169,206]$. HMGB1 and heat shock protein-70 have been proposed to act as TREM-1 ligands [207], and the interaction between TREM-1 and HMGB1 was demonstrated in a murine model [208]. Both the neutrophil-specific antigen, CD177, and the peptidoglycan recognition protein 1, a neutrophil granule protein with antibacterial properties, were also identified as potent TREM-1 ligands $[157,209]$. Finally, other PAMPs, such as the surface glycoprotein of Marburg and Ebola filoviruses [210], were recently included in the list of putative TREM-1 ligands.

TREM-1 engagement on the cell membrane triggers DAP12 association and Src family kinase-mediated ITAM tyrosine phosphorylation $[45,154,156,161]$, followed by GRBP-2, Syk, and ZAP70 recruitment and phosphorylation, which initiate downstream signal transduction events. The signaling pathway mainly involves PI3K, PLC- $\gamma$, ERK1/2, p38 MAP, and Akt serine/threonine kinase activation $[45,154,156,172]$, ultimately triggering intracellular Ca2+ mobilization, actin cytoskeleton rearrangement, and the activation of several transcription complexes $[152,154,160]$, such as STAT5 and NF- $\mathrm{B}$ [179]. The TREM-1 signaling pathway has been recently reviewed $[37,179]$.

\section{TREM-1 Role in Inflammatory Responses and Infectious/Non-Infectious Diseases}

Since the TREM-1 discovery in 2000, extensive progress has been made regarding the elucidation of its biological effects and interaction with other receptor pathways. Due to the absence of a well-characterized ligand, TREM-1 functions have been studied using agonist mAbs, which induce receptor cross-linking. These studies demonstrated that TREM-1 is a key modulator of innate immunity to PAMPs/DAMPs and a major amplifier of MP inflammatory responses induced by PRRs [37,45,153,154,157,161,162,180] (Figure 2). TREM-1 triggering in human Mn was shown to drive the robust production of pro-inflammatory cytokines/chemokines and MMPs [45,171,211]. Microarray analysis showed the TREM-1 contribution to DC and LC pro-inflammatory reprogramming under hypoxic conditions, through the upregulation of genes coding for inflammatory cytokines/chemokines, angiogenic/growth factors, and MMPs [92,110,111,201]. These findings were extended by recent evidence that TREM-1 engagement imparted a pro-inflammatory M1-skewed polarization state to hypoxic macrophages [31].

In vivo, TREM-1 was first identified in sepsis and suggested to be an important diagnostic/prognostic marker in both bacterial and fungal infections. The release of elevated levels of sTREM-1 has been observed in serum samples from septic patients $[162,168,184]$, as well as in 
biologic fluids and inflammatory lesions from patients with lower respiratory tract and pleural infections $[37,154,157,212,213]$. The TREM-1 role as an amplifier of inflammatory responses was confirmed in experimental models of septic shock and other infectious conditions. Recent studies described the TREM-1 involvement in viral and parasite-associated infections and its potential as a biomarker in these diseases $[181,189,192]$. The pharmacologic inhibition of TREM-1 signaling by administration of the TREM-1/Fc fusion protein or siRNAs partially protected animals from acute inflammation and death induced by microbial TLR ligands [37,154,161,162,168,181,186,214-216].

More recent investigations have linked TREM-1 to the occurrence of acute non-infectious inflammatory diseases, such as acute pancreatitis, myocardial ischemia-reperfusion injury, and hemorrhagic shock, as well as to the perpetuation of several chronic inflammatory conditions, including bowel inflammatory disorders, arthritides, atherosclerosis, hypertrophic scars/ulcers, multiple sclerosis, chronic obstructive pulmonary disease, and chronic hepatic granulomatous inflammation [37,110,153,157,178,217-220]. Increased TREM-1 expression levels and sTREM concentrations in various biological fluids were associated with early organ inflammatory injury and dysfunction and suggested to be an indicator of disease activity and severity. This issue is addressed in detail in Reference [37].

\section{TREM-1 Role in Cancer}

Recent investigations using different modulators of TREM-1 signaling have highlighted its critical involvement in inflammation-mediated carcinogenesis (Figure 2). High TREM-1 expression on MPs in mouse and human tumors and/or sTREM-1 release into the biologic fluids of cancer patients were indicated as independent predictors of tumor progression and poor patient prognosis $[37,160]$. (Table 1).

Table 1. TREM-1 mRNA/protein expression in mouse and human tumor-associated MPs and/or sTREM-1 release into the biological fluids of cancer patients.

\begin{tabular}{|c|c|c|c|c|}
\hline Cancer Type & MP Type & Biological Fluid & Effects & References \\
\hline NSCLC & $\begin{array}{l}\text { Macrophages in } \\
\text { tumors and pleural } \\
\text { effusions }\end{array}$ & Pleural effusions & $\begin{array}{l}\text { Correlates with aggressive tumor } \\
\text { behavior, recurrence, poor disease-free, } \\
\text { and overall patient survival }\end{array}$ & {$[194,221,222]$} \\
\hline $\begin{array}{l}\text { Lung } \\
\text { adenocarcinoma }\end{array}$ & $\begin{array}{l}\text { DCs in pleural } \\
\text { effusions }\end{array}$ & ND & $\begin{array}{l}\text { Associates with disease aggressiveness } \\
\text { and bad prognosis }\end{array}$ & [223] \\
\hline Colon carcinoma & $\begin{array}{l}\text { Intestinal } \\
\text { macrophages }\end{array}$ & Serum/plasma & $\begin{array}{l}\text { Amplifies macrophage- mediated } \\
\text { inflammation and intestinal tissue } \\
\text { damage; correlates with aggressive tumor } \\
\text { behavior and recurrence }\end{array}$ & [224-227] \\
\hline $\mathrm{HCC}$ & $\begin{array}{l}\text { Kupffer cells; HSCs; } \\
\text { macrophages in } \\
\text { tumor specimens }\end{array}$ & Plasma & $\begin{array}{l}\text { Increases inflammatory responses, } \\
\text { hepatic injury, tumor development and } \\
\text { aggressive behavior, and poor patient } \\
\text { survival; prognostic predictor for both } \\
\text { early tumor recurrence and low patient } \\
\text { overall and relapse-free survival after } \\
\text { resection; mediates immunosupression }\end{array}$ & {$[205,208,228-231]$} \\
\hline Pancreatic cancer & TAMs & ND & Correlates with cancer progression & {$[232]$} \\
\hline T-cell lymphoma & MDSCs; TAMs & ND & Correlates with increased tumor volume & {$[182]$} \\
\hline Cervical cancer & Monocytes & ND & $\begin{array}{l}\text { Correlates with high-grade, } \\
\text { invasive cancer }\end{array}$ & [233] \\
\hline Glioblastoma & TAMs & ND & $\begin{array}{l}\text { Associates with low outcome of } \\
\text { chemotherapy-treated patients }\end{array}$ & [202] \\
\hline
\end{tabular}

Abbreviations: NSCLC, non-small cell lung cancer; HCCs, hepatocellular carcinoma; HSCs, HCC-activated hepatic stellate cells; TAMs, tumor-associated macrophages; MDSC, myeloid-derived suppressor cells; ND, not determined.

Growing evidence points to a causal role of TREM-1 in chronic inflammation-mediated lung cancer. In normal pulmonary tissue, TREM-1 is selectively expressed in alveolar macrophages, which specialize in pathogen and apoptotic cell clearance. Analysis of surgical specimens from NSCLC patients 
demonstrated a high number of TREM-1+ macrophages in tumor tissues and pleural effusions, that was associated with elevated sTREM-1 concentrations and correlated with aggressive tumor behavior, recurrence, and poor patient survival, suggesting that TREM-1+ macrophages are critical players in NSCLC development and progression [194,221,222]. Lung cancer cells directly promoted TREM-1 upregulation, sTREM-1 release, and pro-inflammatory cytokine secretion in primary Mn/macrophages from NSCLC patients [194,221]. TREM-1 involvement in NSCLC progression was further demonstrated by the finding that TREM-1 engagement by an agonist mAb in macrophages increased NSCLC's cell invasive ability, which was suppressed upon TREM-1 inhibition by shRNA [221]. TREM-1+ DCs accumulation in pleural effusions from patients with lung adenocarcinoma also seems to be associated with disease aggressiveness and bad prognosis [223].

IBDs are a group of chronic gastrointestinal disorders caused by genetics and environmental factors and characterized by bowel chronic inflammation associated with increased risk of colorectal and small bowel cancers [234]. Severe and diffuse mucosal inflammation develops with the production of inflammatory mediators and ulceration. TREM-1 appears to be crucially implicated in IBD pathogenesis and progression to colon tumorigenesis [224,225]. In normal human intestine, only a small fraction of resident macrophages express TREM-1, probably because local IL-10 and TGF $\beta$ prevent excessive activation in response to the flora-rich microenvironment [193]. In contrast, in the mucosa of IBD patients and experimental models of colitis, TREM-1-expressing macrophage infiltration becomes markedly increased, amplifying intestinal inflammation and tissue damage through the secretion of pro-inflammatory mediators [224]. TREM-1-deficiency in mouse models of colitis significantly attenuates disease severity, reduces pro-inflammatory cytokine production and inflammatory infiltrates, and prevents colon carcinoma development/progression, pointing to a pro-oncogenic role of TREM-1 through the amplification of MP inflammatory responses [226]. In addition, increased plasma sTREM concentrations were found in IBD patients [224], representing an indicator of clinical activity $[225,227]$. TREM-1 pharmacologic blockade in vivo in mouse models of colitis confirmed the TREM-1 contribution to the exacerbation and perpetuation of chronic colon inflammation and its progression toward carcinoma development [235] (see Section 7 for details).

TREM-1 was also indicated as a pivotal determinant of HCC development, progression, and poor prognosis [208]. HCC is a well-known inflammation-related cancer, whose pathogenesis is mediated by Kupffer cells in conjunction with recruited inflammatory cells which produce high amounts of inflammatory cytokines after hepatocyte death in the setting of hepatitis or cirrhosis, driving the compensatory proliferation of remaining hepatocytes that ultimately evolves into HCC [228]. TREM-1 mRNA and protein upregulation in liver Kupffer cells was associated with an increased inflammatory response, hepatic injury, and HCC development in a murine model of hepatocellular carcinogenesis, that were attenuated in TREM-1-deficient mice [208]. Another study showed an elevated TREM-1 expression in human HCC-activated hepatic stellate cells (HSCs) from peri-tumoral specimens, associated with HCC aggressive behavior and poor patient survival, serving as an independent prognostic predictor for both early tumor recurrence and low patient overall survival [229]. The sTREM-1 level was higher in the plasma of HCC patients than in those with benign liver tumors [229], suggesting its relevance as a tumor biomarker. Duan et al. [230] further demonstrated a significant correlation among a high TREM-1 expression, pro-inflammatory cytokine secretion, increased HCC proliferation/migration, and decreased HCC patient survival, suggesting a potential prognostic value for postoperative recurrence. Interestingly, a recent study demonstrated that a novel small-molecule STAT3-inhibitor able to block liver inflammation and reduce HCC development/growth in a mouse model of nonalcoholic steatohepatitis exerted a main inhibitory effect on TREM-1 signaling, further linking TREM-1 to the inflammatory processes that promote liver cancer [231]. Finally, Wu et al. [205] recently demonstrated that TREM- ${ }^{+}$TAMs were abundant in advanced-stage HCC within HIF+ areas and associated with poor prognosis, and that, in orthotopic liver tumor models, TREM-1+ TAMs induced immunosuppression by impairing CD8+T cell cytotoxicity while promoting their apoptosis. Interestingly, PD-L1 blockade failed to improve TREM-1+TAM-mediated immunosuppression in 
tumor-bearing mice because of Treg recruitment by the TREM-1-induced CCL20 release in response to the hypoxic environment [205].

TREM-1 upregulation on blood Mn and TAMs phenotypically and functionally resembling myeloid-derived suppressor cells (MDSCs) was reported in mice bearing s.c. T-cell lymphomas, correlating with an increased tumor volume, suggesting its potential contribution to MDSC immune suppressive activity [182].

Finally, a critical role for TREM-1-expressing TAMs in pancreatic cancer progression was shown in xenograft mouse models [232] (see Section 7 for details), and a TREM-1 increased expression was also observed in Mn from patients with invasive cervical cancer [233] and in TAM infiltrating glioblastoma [202].

\section{TREM-1 Therapeutic Targeting}

The evidence that TREM-1 blockade via the TREM-1/Fc protein/antagonist Abs, or genetic deletion/silencing can attenuate inflammatory responses and disease severity in experimental models of microbial infection and inflammation, while treatment with agonist mAbs worsened the disease, indicated the potential of this molecule as a therapeutic target in inflammatory conditions [37,185,191,220,226]. Many efforts have therefore been focused on the development of inhibitors targeting different TREM-1 domains to prevent receptor activation and function [37,157, 178,236]. Two short synthetic peptides, P1 and LP17, derived from the TREM-1 ligand-binding extracellular domain and behaving as decoys for endogenous TREM-1 ligands, have been created and proven to be effective in various preclinical models of microbial infections/sepsis and non-infectious inflammatory conditions by dampening inflammation and protecting from organ damage and death $[37,168,178,184,186,188]$. A ligand-independent peptide inhibitor, GF9, targeting the TREM-1 transmembrane domain and preventing the TREM-1/DAP12 interaction [237], has shown therapeutic efficacy in models of septic shock [37]. Relevant preclinical data have also been obtained using the TREM-1 antagonist peptide, LR12, mimicking a conserved sequence across TREM-1 and the related receptor, TREM-like transcripts-1 [238], in animal models of septic shock and myocardial ischemia (for a review see Reference [37]).

Recently, experimental and human studies have suggested that TREM-1 pharmacologic targeting may represent a potential novel therapeutic modality to inhibit MP-mediated chronic inflammation-associated tumor development, pointing to TREM-1 as an attractive new immunotherapeutic target also for cancer [37,157] (Figure 2, Table 2).

Table 2. Therapeutic effects of TREM-1 targeting by synthetic peptide inhibitors in preclinical mouse models of inflammation-derived malignancies.

\begin{tabular}{|c|c|c|c|}
\hline Cancer Type & TREM-1 Peptide & Therapeutic Effects & References \\
\hline Colon Cancer & LP-17 & $\begin{array}{l}\text { Reduces pro-inflammatory mediator secretion by intestinal } \\
\text { macrophages; attenuates intestinal inflammation, permeability, } \\
\text { and epithelial damage; decreases epithelial histopathological } \\
\text { alterations, proliferative activity, and progression to } \\
\text { colon carcinoma }\end{array}$ & [235] \\
\hline NSCLC & GF9 & Decreases cytokine production and delays tumor growth & [237] \\
\hline $\mathrm{HCC}$ & GF9 & $\begin{array}{l}\text { Reduces tumor development and growth; abrogates } \\
\text { TREM-1+TAM-mediated immunosuppressive effect by reducing } \\
\text { Treg recruitment and CD8+T cell apoptosis/dysfunction; improves } \\
\text { mouse survival; attenuates resistance to PD-L1 blockade } \\
\text { improving its therapeutic efficacy }\end{array}$ & {$[205]$} \\
\hline
\end{tabular}

Abbreviations: NSCLC, non-small cell lung cancer; HCC, hepatocellular carcinoma; TAMs, tumor-associated macrophages; PD-L1, programmed cell death-1 ligand. 
Zhou and coworkers [235] demonstrated that TREM-1 blocking by the administration of the LP17 peptide antagonist had therapeutic effects in a mouse model of colon carcinogenesis, reducing the histopathological alterations and tumor formation associated with decreased levels of pro-inflammatory cytokine production by intestinal macrophages and epithelial proliferation, suggesting that treatment can attenuate intestinal macrophage-mediated inflammation and progression to colon carcinoma [235].

The GF9 effects were explored in two human NSCLC xenograft models. TREM-1 blockade by the administration of the GF9 inhibitory peptide significantly suppressed tumor growth, and the therapeutic efficacy was increased by the peptide incorporation into synthetic high-density lipoprotein nanoparticles to extend its half-life and specifically target delivery to macrophages, supporting the TREM-1 potential as a target for adjunctive therapy in lung cancer treatment [237]. The GF9 peptide also showed therapeutic potential against pancreatic cancer. Its administration in three human pancreatic cancer xenograft mouse models resulted in a strong anti-tumor effect, which was significantly correlated with the suppression of TAM infiltration, reduction of pro-inflammatory cytokine serum levels, and increased animal survival [232]. In addition, blocking TREM-1 signaling with GF9 treatment in orthotopic HCC-bearing models abrogated the TREM-1 $1^{+}$TAM-mediated immunosuppressive effects by significantly reducing Treg recruitment and $\mathrm{CD} 8^{+} \mathrm{T}$ cell apoptosis/dysfunction, showing inhibitory effects on tumor growth and improving mouse survival [205]. Interestingly, GF9 treatment also significantly attenuated resistance to PD-L1 blockade, improving its therapeutic efficacy [205].

These data suggest that TREM-1-specific peptide inhibitors have a cancer type-independent anti-tumor activity and can potentially be used as a stand-alone therapy or as a component of combinational therapy for several types of solid tumors.

\section{Concluding Remarks}

In this review, we have summarized some general trends emerging from the published data concerning MPs' role in the inflammatory circuit that promotes tumor progression and their potential as effectors of cancer immunotherapy. Outlined studies emphasize the complex level of control exerted by PRRs and IRS receptors expressed on MPs on the development and perpetuation of chronic inflammatory conditions that predispose patients to cancer and highlight the promises of their targeting with specific $\mathrm{mAbs}$ or agonist/antagonist ligands to reprogram immunosuppressive/ pro-tumoral MPs toward an anti-tumor direction. A clear conclusion is that MP receptor-targeted immunotherapeutic approaches have the potential to complement and synergize with current treatments to improve their efficacy. The identification of novel targets of treatment would be helpful to create new combination anti-cancer therapies.

The TREM-1 pharmacological inhibition with specific peptide inhibitors has recently proven to be effective in various mouse models of chronic inflammation-associated malignancies, conferring protection from tumor growth and survival advantages through the attenuation of MP inflammatory responses, pointing to TREM- 1 as a novel attractive target for clinical application in cancer. The advantage of such an approach is that it blunts, but does not totally abrogate, inflammatory responses, which are essential for tumor control. So far, however, the therapeutic use of TREM-1 inhibitors has been limited to preclinical models, and only studies designed to measure the prognostic/diagnostic value of TREM-1 expression and/or sTREM-1 levels in samples from patients with inflammation-associated cancer have been carried out $[37,157]$. Recently, a phase I clinical trial has been run to evaluate the safety, tolerability, and pharmacokinetics of the synthetic peptide nangibotide (LR12), the first drug candidate targeting TREM-1 to reach clinical stage development [239], and future assessment of this agent for cancer therapy is expected.

Therapeutic applications directed to TREM-1 revolve around antagonizing its function. Small synthetic peptide antagonists have been widely tested because of their low immunogenicity [157]. The TREM-1/Fc fusion protein has emerged by studies in microbial sepsis $[162,240,241]$ and other inflammatory conditions $[185,220,242,243]$ as an alternative TREM-1 inhibitor, potentially able to overcome the limited pharmacological effects of synthetic peptides in humans due to their short 
half-life. Studies to derive new peptides or small molecules able to counteract the TREM-1 pro-tumoral effects, but also to activate innate immunity via TREM-1/DAP12 pathways in the context of vaccination, are currently ongoing (for a review see Reference [157]). Clinical testing of antagonist anti-TREM-1 Abs is likewise warranted because Abs bind directly to TREM-1, whereas peptides might only bind to its ligands or DAP12 (Table 2). A better understanding of the identity of the TREM-1 ligand might reveal novel targets for tumor treatment.

Further research is crucial before immunotherapeutic strategies based on TREM-1 targeting could be translated into clinical settings. Divergent results were in fact reported by Zhang et al. [244], who showed that TREM-1 expression in TAMs and Mn were decreased during lung tumor progression. An additional level of complexity is given by the evidence of TREM-1 expression on other myeloid and non-myeloid cells involved in anti-tumor responses [37]. TREM-1 is highly expressed in neutrophils, where its activation results in ROS, lactoferrin, myeloperoxidase, and NO production, with consequent increased neutrophil degranulation, oxidative burst, and phagocytosis [45,156,173]. In addition, this molecule has been recently reported to be required for successful NK cell anti-tumor activity in a mouse lung tumor model. Lee et al. [245] demonstrated that lung tumor development and metastasis were suppressed via an increase in TREM-1-dependent NK cell cytotoxicity. TREM-1 blockade with LP-17 prevented NK cell killing, whereas TREM-1 mAb recovered NK cytotoxic effects. Under this scenario, the inhibition of TREM-1 would lead to increased tumor growth. Therapeutic effects of TREM-1 targeting will thus be ultimately dictated by the functional interplay among the different TREM-1+ immune cell populations recruited to tumor sites, suggesting that caution should be exerted in modulating its activity.

Finally, evidence linking low $\mathrm{pO}_{2}, \mathrm{HIF}-1$ expression, deregulated MP receptor expression/activities, and MP pro-tumoral activation at tumor sites have potential implications for the design of new HIF-1-targeted therapies (Figure 2). The inhibition of hypoxia-mediated tumor promotion by blocking the HIF-1 expression/activity is currently being investigated as a therapeutic approach for various malignancies [91]. Several putative small molecule HIF-1 inhibitors have been tested in clinical trials $[82,246,247]$ and may have potential efficacy in counteracting MP receptor deregulation and promoting MP anti-tumor responses.

Author Contributions: F.R. revised the manuscript and prepared the figures; M.C.B. conceptualized, wrote, and edited the manuscript. All authors have read and agreed to the published version of the manuscript.

Funding: This work was supported by grants from the Italian Ministry of Health (Ricerca Finalizzata RF-2016-02361048).

Conflicts of Interest: The authors declare no conflict of interest.

$\begin{array}{ll}\text { Abbreviations } & \\ \text { TME } & \text { tumor microenvironment } \\ \text { IBD } & \text { inflammatory bowels disease } \\ \text { MPs } & \text { mononuclear phagocytes } \\ \text { PAMPs/DAMPs } & \text { pathogen- or damage-associated molecular patterns } \\ \text { TREM 1 } & \text { triggering receptor expressed on myeloid cells } \\ \text { Mn } & \text { monocytes } \\ \text { TAMs } & \text { tumor-associated macrophages } \\ \text { TADCs } & \text { tumor-associated dendritic cells } \\ \text { ROS } & \text { reactive oxygen species } \\ \text { NO } & \text { nitric oxide } \\ \text { pO2 } & \text { partial oxygen pressure } \\ \text { PRRs } & \text { pattern recognition receptors } \\ \text { IRS } & \text { immunoregulatory signaling } \\ \text { ADCC } & \text { Ab-dependent cell-mediated cytotoxicity } \\ \text { TLRs } & \text { toll-like receptors } \\ \text { MSR } & \text { macrophage scavenger receptor 1 }\end{array}$




$\begin{array}{ll}\text { MARCO } & \text { macrophage receptor with collagenous structure } \\ \text { NSCLC } & \text { non-small cell lung cancer } \\ \text { SIRP } \alpha & \text { signal regulatory protein-alpha } \\ \text { CD47 } & \text { cluster of differentiation 47 } \\ \text { PD1 } & \text { programmed cell death-1 } \\ \text { PDL1 } & \text { programmed cell death-1 ligand } \\ \text { LILRB1 } & \text { leukocyte immunoglobulin-like receptor B1 } \\ \beta 2 M & \text { ß2-microglobulin } \\ \text { TIM-3 } & \text { T cell Ig and mucin domain 3 } \\ \text { HMGB1 } & \text { high mobility group box 1 } \\ \text { mAbs } & \text { monoclonal antibodies } \\ \text { FCRs } & \text { Fc region of Igs } \\ \text { ADP } & \text { Ab-dependent phagocytosis } \\ \text { CYT } & \text { cytoplasmic tail } \\ \text { DAP12 } & \text { DNA activating protein 12 } \\ \text { ITAM } & \text { immunoreceptor tyrosine-based activatory motif } \\ \text { sTREM-1 } & \text { soluble TREM-1 } \\ \text { MMP } & \text { metalloproteinase } \\ \text { LCs } & \text { Langerhans cells } \\ \text { HRE } & \text { hypoxia response element } \\ \text { HIF1 } & \text { hypoxia-inducible transcription factor } \\ \text { HCC } & \text { hepatocellular carcinoma } \\ \text { siRNA } & \text { small interfering RNA } \\ \text { HSCs } & \text { hepatic stellate cells } \\ & \end{array}$

\section{References}

1. Coussens, L.M.; Werb, Z. Inflammation and cancer. Nature 2002, 420, 860-867. [CrossRef] [PubMed]

2. Hanahan, D.; Weinberg, R.A. Hallmarks of cancer: The next generation. Cell 2011, 144, 646-674. [CrossRef] [PubMed]

3. Gonzalez, H.; Hagerling, C.; Werb, Z. Roles of the immune system in cancer: From tumor initiation to metastatic progression. Genes Dev. 2018, 32, 1267-1284. [CrossRef] [PubMed]

4. Cassetta, L.; Pollard, J.W. Targeting macrophages: Therapeutic approaches in cancer. Nat. Rev. Drug Discov. 2018, 17, 887-904. [CrossRef]

5. Kitamura, T.; Qian, B.Z.; Pollard, J.W. Immune cell promotion of metastasis. Nat. Rev. Immunol. 2015, 15, 73-86. [CrossRef]

6. Mantovani, A.; Allavena, P.; Sica, A.; Balkwill, F. Cancer-related inflammation. Nature 2008, 454, $436-444$. [CrossRef]

7. Colotta, F.; Allavena, P.; Sica, A.; Garlanda, C.; Mantovani, A. Cancer-related inflammation, the seventh hallmark of cancer: Links to genetic instability. Carcinogenesis 2009, 30, 1073-1081. [CrossRef]

8. Bosch, F.X.; Lorincz, A.; Munoz, N.; Meijer, C.J.; Shah, K.V. The causal relation between human papillomavirus and cervical cancer. J. Clin. Pathol. 2002, 55, 244-265. [CrossRef]

9. Svrcek, M.; Borralho, N.P.; Villanacci, V.; Beaugerie, L.; Rogler, G.; De Hertogh, G.; Tripathi, M.; Feakins, R. Clinicopathological and Molecular Specificities of Inflammatory Bowel Disease-Related Colorectal Neoplastic Lesions: The Role of Inflammation. J. Crohn's Colitis 2018, 12, 1486-1498. [CrossRef]

10. Ponzoni, M.; Pastorino, F.; Di, P.D.; Perri, P.; Brignole, C. Targeting Macrophages as a Potential Therapeutic Intervention: Impact on Inflammatory Diseases and Cancer. Int. J. Mol. Sci. 2018, 19, 1953. [CrossRef]

11. Mantovani, A.; Marchesi, F.; Malesci, A.; Laghi, L.; Allavena, P. Tumour-associated macrophages as treatment targets in oncology. Nat. Rev. Clin. Oncol. 2017, 14, 399-416. [CrossRef] [PubMed]

12. de Visser, K.E.; Coussens, L.M. The interplay between innate and adaptive immunity regulates cancer development. Cancer Immunol. Immunother. 2005, 54, 1143-1152. [CrossRef] [PubMed]

13. LaGory, E.L.; Giaccia, A.J. The ever-expanding role of HIF in tumour and stromal biology. Nat. Cell Biol. 2016, 18, 356-365. [CrossRef] [PubMed] 
14. Trinchieri, G. Cancer and inflammation: An old intuition with rapidly evolving new concepts. Annu. Rev. Immunol. 2012, 30, 677-706. [CrossRef] [PubMed]

15. Ben Baruch, A. Inflammation-associated immune suppression in cancer: The roles played by cytokines, chemokines and additional mediators. Semin. Cancer Biol. 2006, 16, 38-52. [CrossRef]

16. Rahat, M.A.; Marom, B.; Bitterman, H.; Weiss-Cerem, L.; Kinarty, A.; Lahat, N. Hypoxia reduces the output of matrix metalloproteinase-9 (MMP-9) in monocytes by inhibiting its secretion and elevating membranal association. J. Leukoc. Biol. 2006, 79, 706-718. [CrossRef]

17. Shalapour, S.; Karin, M. Immunity, inflammation, and cancer: An eternal fight between good and evil. J. Clin. Investig. 2015, 125, 3347-3355. [CrossRef]

18. Murdoch, C.; Giannoudis, A.; Lewis, C.E. Mechanisms regulating the recruitment of macrophages into hypoxic areas of tumors and other ischemic tissues. Blood 2004, 104, 2224-2234. [CrossRef]

19. Knowles, H.J.; Harris, A.L. Macrophages and the hypoxic tumour microenvironment. Front Biosci. 2007, 12, 4298-4314. [CrossRef]

20. Mantovani, A.; Sica, A. Macrophages, innate immunity and cancer: Balance, tolerance, and diversity. Curr. Opin. Immunol. 2010, 22, 231-237. [CrossRef]

21. Qian, B.Z.; Pollard, J.W. Macrophage diversity enhances tumor progression and metastasis. Cell 2010, 141, 39-51. [CrossRef] [PubMed]

22. Vitale, I.; Manic, G.; Coussens, L.M.; Kroemer, G.; Galluzzi, L. Macrophages and Metabolism in the Tumor Microenvironment. Cell Metab. 2019, 30, 36-50. [CrossRef] [PubMed]

23. Allavena, P.; Mantovani, A. Immunology in the clinic review series; focus on cancer: Tumour-associated" macrophages: Undisputed stars of the inflammatory tumour microenvironment. Clin. Exp. Immunol. 2012, 167, 195-205. [CrossRef] [PubMed]

24. Stout, R.D.; Jiang, C.; Matta, B.; Tietzel, I.; Watkins, S.K.; Suttles, J. Macrophages sequentially change their functional phenotype in response to changes in microenvironmental influences. J. Immunol. 2005, 175, 342-349. [CrossRef] [PubMed]

25. Bosco, M.C.; Puppo, M.; Blengio, F.; Fraone, T.; Cappello, P.; Giovarelli, M.; Varesio, L. Monocytes and dendritic cells in a hypoxic environment: Spotlights on chemotaxis and migration. Immunobiology 2008, 213, 733-749. [CrossRef] [PubMed]

26. Martinez, F.O.; Sica, A.; Mantovani, A.; Locati, M. Macrophage activation and polarization. Front. Biosci. 2008, 13, 453-461. [CrossRef]

27. Davis, M.J.; Tsang, T.M.; Qiu, Y.; Dayrit, J.K.; Freij, J.B.; Huffnagle, G.B.; Olszewski, M.A. Macrophage M1/M2 polarization dynamically adapts to changes in cytokine microenvironments in Cryptococcus neoformans infection. MBio 2013, 4, e00264-13. [CrossRef]

28. Bosco, M.C.; Rapisarda, A.; Reffo, G.; Massazza, S.; Pastorino, S.; Varesio, L. Macrophage activating properties of the tryptophan catabolite picolinic acid. Adv. Exp. Med. Biol. 2003, 527, 55-65.

29. Gratchev, A.; Kzhyshkowska, J.; Kothe, K.; Muller-Molinet, I.; Kannookadan, S.; Utikal, J.; Goerdt, S. Mphi1 and Mphi2 can be re-polarized by Th2 or Th1 cytokines, respectively, and respond to exogenous danger signals. Immunobiology 2006, 211, 473-486. [CrossRef]

30. Martinez, F.O.; Gordon, S. The M1 and M2 paradigm of macrophage activation: Time for reassessment. F1000Prime Rep. 2014, 6, 13. [CrossRef]

31. Raggi, F.; Pelassa, S.; Pierobon, D.; Penco, F.; Gattorno, M.; Novelli, F.; Eva, A.; Varesio, L.; Giovarelli, M.; Bosco, M.C. Regulation of Human Macrophage M1-M2 Polarization Balance by Hypoxia and the Triggering Receptor Expressed on Myeloid Cells-1. Front. Immunol. 2017, 8, 1097. [CrossRef] [PubMed]

32. Bosco, M.C. Macrophage polarization: Reaching across the aisle? J. Allergy Clin. Immunol. 2019, 143, 1348-1350. [CrossRef] [PubMed]

33. Granucci, F.; Zanoni, I.; Ricciardi-Castagnoli, P. Central role of dendritic cells in the regulation and deregulation of immune responses. Cell Mol. Life Sci. 2008, 65, 1683-1697. [CrossRef] [PubMed]

34. Munitz, A. Inhibitory receptors on myeloid cells: New targets for therapy? Pharmacol. Ther. 2010, 125, 128-137. [CrossRef] [PubMed]

35. Gerber, J.S.; Mosser, D.M. Stimulatory and inhibitory signals originating from the macrophage Fcgamma receptors. Microbes Infect. 2001, 3, 131-139. [CrossRef]

36. Colonna, M.; Nakajima, H.; Cella, M. A family of inhibitory and activating Ig-like receptors that modulate function of lymphoid and myeloid cells. Semin. Immunol. 2000, 12, 121-127. [CrossRef] 
37. Bosco, M.C.; Raggi, F.; Varesio, L. Therapeutic Potential of Targeting TREM-1 in Inflammatory Diseases and Cancer. Curr. Pharm. Des. 2016, 22, 6209-6233. [CrossRef]

38. Kawai, T.; Akira, S. Toll-like receptors and their crosstalk with other innate receptors in infection and immunity. Immunity 2011, 34, 637-650. [CrossRef]

39. Takeuchi, O.; Akira, S. Pattern recognition receptors and inflammation. Cell 2010, 140, 805-820. [CrossRef]

40. DeNardo, D.G.; Ruffell, B. Macrophages as regulators of tumour immunity and immunotherapy. Nat. Rev. Immunol. 2019, 19, 369-382. [CrossRef]

41. DeNardo, D.G.; Brennan, D.J.; Rexhepaj, E.; Ruffell, B.; Shiao, S.L.; Madden, S.F.; Gallagher, W.M.; Wadhwani, N.; Keil, S.D.; Junaid, S.A.; et al. Leukocyte complexity predicts breast cancer survival and functionally regulates response to chemotherapy. Cancer Discov. 2011, 1, 54-67. [CrossRef] [PubMed]

42. Brown, J.M.; Recht, L.; Strober, S. The Promise of Targeting Macrophages in Cancer Therapy. Clin. Cancer Res. 2017, 23, 3241-3250. [CrossRef] [PubMed]

43. Cortese, N.; Donadon, M.; Rigamonti, A.; Marchesi, F. Macrophages at the crossroads of anticancer strategies. Front. Biosci. 2019, 24, 1271-1283.

44. Klesney-Tait, J.; Turnbull, I.R.; Colonna, M. The TREM receptor family and signal integration. Nat. Immunol. 2006, 7, 1266-1273. [CrossRef] [PubMed]

45. Bouchon, A.; Dietrich, J.; Colonna, M. Cutting edge: Inflammatory responses can be triggered by TREM-1, a novel receptor expressed on neutrophils and monocytes. J. Immunol. 2000, 164, 4991-4995. [CrossRef]

46. Bennaceur, K.; Chapman, J.; Brikci-Nigassa, L.; Sanhadji, K.; Touraine, J.L.; Portoukalian, J. Dendritic cells dysfunction in tumour environment. Cancer Lett. 2008, 272, 186-196. [CrossRef]

47. Schmieder, A.; Michel, J.; Schonhaar, K.; Goerdt, S.; Schledzewski, K. Differentiation and gene expression profile of tumor-associated macrophages. Semin. Cancer Biol. 2012, 22, 289-297. [CrossRef]

48. Vicari, A.P.; Caux, C.; Trinchieri, G. Tumour escape from immune surveillance through dendritic cell inactivation. Semin. Cancer Biol. 2002, 12, 33-42. [CrossRef]

49. Lin, K.W.; Jacek, T.; Jacket, R. Dendritic cells heterogeneity and its role in cancer immunity. Cancer Res. 2006, 2, 35-40.

50. Nielsen, S.R.; Schmid, M.C. Macrophages as Key Drivers of Cancer Progression and Metastasis. Mediat. Inflamm. 2017, 2017, 9624760. [CrossRef]

51. Banchereau, J.; Briere, F.; Caux, C.; Davoust, J.; Lebecque, S.; Liu, Y.J.; Pulendran, B.; Palucka, K. Immunobiology of dendritic cells. Annu. Rev. Immunol. 2000, 18,767-811. [CrossRef] [PubMed]

52. Cavanagh, L.L.; Von Andrian, U.H. Travellers in many guises: The origins and destinations of dendritic cells. Immunol. Cell Biol 2002, 80, 448-462. [CrossRef] [PubMed]

53. Lamagna, C.; Aurrand-Lions, M.; Imhof, B.A. Dual role of macrophages in tumor growth and angiogenesis. J. Leukoc. Biol. 2006, 80, 705-713. [CrossRef] [PubMed]

54. Gordon, S.; Martinez, F.O. Alternative activation of macrophages: Mechanism and functions. Immunity 2010, 32, 593-604. [CrossRef] [PubMed]

55. Sica, A.; Bronte, V. Altered macrophage differentiation and immune dysfunction in tumor development. J. Clin. Investig. 2007, 117, 1155-1166. [CrossRef] [PubMed]

56. Lewis, C.E.; Pollard, J.W. Distinct role of macrophages in different tumor microenvironments. Cancer Res. 2006, 66, 605-612. [CrossRef] [PubMed]

57. Sica, A.; Mantovani, A. Macrophage plasticity and polarization: In vivo veritas. J. Clin. Investig. 2012, 122, 787-795. [CrossRef]

58. Khallou-Laschet, J.; Varthaman, A.; Fornasa, G.; Compain, C.; Gaston, A.T.; Clement, M.; Dussiot, M.; Levillain, O.; Graff-Dubois, S.; Nicoletti, A.; et al. Macrophage plasticity in experimental atherosclerosis. PLoS ONE 2010, 5, e8852. [CrossRef]

59. Zeyda, M.; Farmer, D.; Todoric, J.; Aszmann, O.; Speiser, M.; Gyori, G.; Zlabinger, G.J.; Stulnig, T.M. Human adipose tissue macrophages are of an anti-inflammatory phenotype but capable of excessive pro-inflammatory mediator production. Int. J. Obes. 2007, 31, 1420-1428. [CrossRef]

60. Murray, P.J.; Allen, J.E.; Biswas, S.K.; Fisher, E.A.; Gilroy, D.W.; Goerdt, S.; Gordon, S.; Hamilton, J.A.; Ivashkiv, L.B.; Lawrence, T.; et al. Macrophage activation and polarization: Nomenclature and experimental guidelines. Immunity 2014, 41, 14-20. [CrossRef] 
61. Laoui, D.; Van Overmeire, E.; Di Conza, G.; Aldeni, C.; Keirsse, J.; Morias, Y.; Movahedi, K.; Houbracken, I.; Schouppe, E.; Elkrim, Y.; et al. Tumor hypoxia does not drive differentiation of tumor-associated macrophages but rather fine-tunes the M2-like macrophage population. Cancer Res. 2014, 74, 24-30. [CrossRef] [PubMed]

62. Allavena, P.; Sica, A.; Garlanda, C.; Mantovani, A. The Yin-Yang of tumor-associated macrophages in neoplastic progression and immune surveillance. Immunol. Rev. 2008, 222, 155-161. [CrossRef] [PubMed]

63. Zhao, X.; Qu, J.; Sun, Y.; Wang, J.; Liu, X.; Wang, F.; Zhang, H.; Wang, W.; Ma, X.; Gao, X.; et al. Prognostic significance of tumor-associated macrophages in breast cancer: A meta-analysis of the literature. Oncotarget 2017, 8, 30576-30586. [CrossRef] [PubMed]

64. Cao, J.; Liu, J.; Xu, R.; Zhu, X.; Zhao, X.; Qian, B.Z. Prognostic role of tumour-associated macrophages and macrophage scavenger receptor 1 in prostate cancer: A systematic review and meta-analysis. Oncotarget 2017, 8, 83261-83269. [CrossRef]

65. Yin, S.; Huang, J.; Li, Z.; Zhang, J.; Luo, J.; Lu, C.; Xu, H.; Xu, H. The Prognostic and Clinicopathological Significance of Tumor-Associated Macrophages in Patients with Gastric Cancer: A Meta-Analysis. PLoS ONE 2017, 12, e0170042. [CrossRef] [PubMed]

66. Mei, J.; Xiao, Z.; Guo, C.; Pu, Q.; Ma, L.; Liu, C.; Lin, F.; Liao, H.; You, Z.; Liu, L. Prognostic impact of tumor-associated macrophage infiltration in non-small cell lung cancer: A systemic review and meta-analysis. Oncotarget 2016, 7, 34217-34228. [CrossRef]

67. Guo, B.; Cen, H.; Tan, X.; Ke, Q. Meta-analysis of the prognostic and clinical value of tumor-associated macrophages in adult classical Hodgkin lymphoma. BMC Med. 2016, 14, 159. [CrossRef]

68. Zhang, Q.W.; Liu, L.; Gong, C.Y.; Shi, H.S.; Zeng, Y.H.; Wang, X.Z.; Zhao, Y.W.; Wei, Y.Q. Prognostic significance of tumor-associated macrophages in solid tumor: A meta-analysis of the literature. PLoS ONE 2012, 7, e50946. [CrossRef]

69. Rossi, M.; Young, J.W. Human dendritic cells: Potent antigen-presenting cells at the crossroads of innate and adaptive immunity. J. Immunol. 2005, 175, 1373-1381. [CrossRef]

70. Steinman, R.M.; Banchereau, J. Taking dendritic cells into medicine. Nature 2007, 449, 419-426. [CrossRef]

71. Ueno, H.; Klechevsky, E.; Morita, R.; Aspord, C.; Cao, T.; Matsui, T.; Di Pucchio, T.; Connolly, J.; Fay, J.W.; Pascual, V.; et al. Dendritic cell subsets in health and disease. Immunol. Rev. 2007, 219, 118-142. [CrossRef]

72. Tran Janco, J.M.; Lamichhane, P.; Karyampudi, L.; Knutson, K.L. Tumor-infiltrating dendritic cells in cancer pathogenesis. J. Immunol. 2015, 194, 2985-2991. [CrossRef]

73. Lin, A.; Schildknecht, A.; Nguyen, L.T.; Ohashi, P.S. Dendritic cells integrate signals from the tumor microenvironment to modulate immunity and tumor growth. Immunol. Lett. 2010, 127, 77-84. [CrossRef]

74. Krempski, J.; Karyampudi, L.; Behrens, M.D.; Erskine, C.L.; Hartmann, L.; Dong, H.; Goode, E.L.; Kalli, K.R.; Knutson, K.L. Tumor-infiltrating programmed death receptor-1+ dendritic cells mediate immune suppression in ovarian cancer. J. Immunol. 2011, 186, 6905-6913. [CrossRef]

75. Huarte, E.; Cubillos-Ruiz, J.R.; Nesbeth, Y.C.; Scarlett, U.K.; Martinez, D.G.; Buckanovich, R.J.; Benencia, F.; Stan, R.V.; Keler, T.; Sarobe, P.; et al. Depletion of dendritic cells delays ovarian cancer progression by boosting antitumor immunity. Cancer Res. 2008, 68, 7684-7691. [CrossRef]

76. Gabrilovich, D. Mechanisms and functional significance of tumour-induced dendritic-cell defects. Nat. Rev. Immunol. 2004, 4, 941-952. [CrossRef]

77. Allavena, P.; Sica, A.; Vecchi, A.; Locati, M.; Sozzani, S.; Mantovani, A. The chemokine receptor switch paradigm and dendritic cell migration: Its significance in tumor tissues. Immunol. Rev. 2000, 177, 141-149. [CrossRef]

78. Semenza, G.L. Oxygen sensing, homeostasis, and disease. N. Engl. J. Med. 2011, 365, 537-547. [CrossRef]

79. Imtiyaz, H.Z.; Simon, M.C. Hypoxia-inducible factors as essential regulators of inflammation. Curr. Top. Microbiol. Immunol. 2010, 345, 105-120.

80. Noman, M.Z.; Hasmim, M.; Messai, Y.; Terry, S.; Kieda, C.; Janji, B.; Chouaib, S. Hypoxia: A key player in antitumor immune response. A Review in the Theme: Cellular Responses to Hypoxia. Am. J. Physiol. Cell Physiol. 2015, 309, C569-C579. [CrossRef]

81. Vaupel, P.; Hockel, M. Tumor oxygenation and its relevance to tumor physiology and treatment. Adv. Exp. Med. Biol. 2003, 510, 45-49.

82. Bosco, M.C.; D'Orazi, G.; Del, B.D. Targeting hypoxia in tumor: A new promising therapeutic strategy. J. Exp. Clin. Cancer Res. 2020, 39, 8. [CrossRef] 
83. Lu, X.; Kang, Y. Hypoxia and hypoxia-inducible factors: Master regulators of metastasis. Clin. Cancer Res. 2010, 16, 5928-5935. [CrossRef]

84. Palazon, A.; Aragones, J.; Morales-Kastresana, A.; de Landazuri, M.O.; Melero, I. Molecular pathways: Hypoxia response in immune cells fighting or promoting cancer. Clin. Cancer Res. 2012, 18, 1207-1213. [CrossRef]

85. Sica, A.; Melillo, G.; Varesio, L. Hypoxia: A double-edged sword of immunity. J. Mol. Med. 2011, 89, 657-665. [CrossRef]

86. Sitkovsky, M.; Lukashev, D. Regulation of immune cells by local-tissue oxygen tension: HIF1 alpha and adenosine receptors. Nat. Rev. Immunol. 2008, 5, 712-721. [CrossRef]

87. Multhoff, G.; Vaupel, P. Hypoxia Compromises Anti-Cancer Immune Responses. Adv. Exp. Med. Biol. 2020, $1232,131-143$.

88. Westendorf, A.M.; Skibbe, K.; Adamczyk, A.; Buer, J.; Geffers, R.; Hansen, W.; Pastille, E.; Jendrossek, V. Hypoxia Enhances Immunosuppression by Inhibiting CD4+ Effector T Cell Function and Promoting Treg Activity. Cell Physiol. Biochem. 2017, 41, 1271-1284. [CrossRef]

89. Parodi, M.; Raggi, F.; Cangelosi, D.; Manzini, C.; Balsamo, M.; Blengio, F.; Eva, A.; Varesio, L.; Pietra, G.; Moretta, L.; et al. Hypoxia Modifies the Transcriptome of Human NK Cells, Modulates Their Immunoregulatory Profile, and Influences NK Cell Subset Migration. Front. Immunol. 2018, 9, 2358. [CrossRef]

90. Terry, S.; Buart, S.; Chouaib, S. Hypoxic Stress-Induced Tumor and Immune Plasticity, Suppression, and Impact on Tumor Heterogeneity. Front. Immunol. 2017, 8, 1625. [CrossRef]

91. Triner, D.; Shah, Y.M. Hypoxia-inducible factors: A central link between inflammation and cancer. J. Clin. Investig. 2016, 126, 3689-3698. [CrossRef]

92. Bosco, M.C.; Varesio, L. Dendritic cell reprogramming by the hypoxic environment. Immunobiology 2012, 217, 1241-1249. [CrossRef]

93. Tripathi, C.; Tewari, B.N.; Kanchan, R.K.; Baghel, K.S.; Nautiyal, N.; Shrivastava, R.; Kaur, H.; Bhatt, M.L.; Bhadauria, S. Macrophages are recruited to hypoxic tumor areas and acquire a pro-angiogenic M2-polarized phenotype via hypoxic cancer cell derived cytokines Oncostatin M and Eotaxin. Oncotarget 2014, 5, 5350-5368. [CrossRef]

94. Escribese, M.M.; Casas, M.; Corbi, A.L. Influence of low oxygen tensions on macrophage polarization. Immunobiology 2012, 217, 1233-1240. [CrossRef]

95. Bosco, M.C.; Varesio, L. Hypoxia and Gene Expression. In Hypoxia and Cancer. Biological Implications and Therapeutic Opportunities; Melillo, G., Ed.; Humana Press: Totowa, NJ, USA, 2014; pp. 91-119.

96. Leblond, M.M.; Gerault, A.N.; Corroyer-Dulmont, A.; MacKenzie, E.T.; Petit, E.; Bernaudin, M.; Valable, S. Hypoxia induces macrophage polarization and re-education toward an M2 phenotype in U87 and U251 glioblastoma models. Oncoimmunology 2016, 5, e1056442. [CrossRef]

97. Zhang, J.; Cao, J.; Ma, S.; Dong, R.; Meng, W.; Ying, M.; Weng, Q.; Chen, Z.; Ma, J.; Fang, Q.; et al. Tumor hypoxia enhances Non-Small Cell Lung Cancer metastasis by selectively promoting macrophage M2 polarization through the activation of ERK signaling. Oncotarget 2014, 5, 9664-9677. [CrossRef]

98. Guo, X.; Xue, H.; Shao, Q.; Wang, J.; Guo, X.; Chen, X.; Zhang, J.; Xu, S.; Li, T.; Zhang, P.; et al. Hypoxia promotes glioma-associated macrophage infiltration via periostin and subsequent $\mathrm{M} 2$ polarization by upregulating TGF-beta and M-CSFR. Oncotarget 2016, 7, 80521. [CrossRef]

99. Zeng, Q.; Jewell, C.M. Directing toll-like receptor signaling in macrophages to enhance tumor immunotherapy. Curr. Opin. Biotechnol. 2019, 60, 138-145. [CrossRef]

100. Fang, W.B.; Yao, M.; Brummer, G.; Acevedo, D.; Alhakamy, N.; Berkland, C.; Cheng, N. Targeted gene silencing of CCL2 inhibits triple negative breast cancer progression by blocking cancer stem cell renewal and M2 macrophage recruitment. Oncotarget 2016, 7, 49349-49367. [CrossRef]

101. Moisan, F.; Francisco, E.B.; Brozovic, A.; Duran, G.E.; Wang, Y.C.; Chaturvedi, S.; Seetharam, S.; Snyder, L.A.; Doshi, P.; Sikic, B.I. Enhancement of paclitaxel and carboplatin therapies by CCL2 blockade in ovarian cancers. Mol. Oncol. 2014, 8, 1231-1239. [CrossRef]

102. Sandhu, S.K.; Papadopoulos, K.; Fong, P.C.; Patnaik, A.; Messiou, C.; Olmos, D.; Wang, G.; Tromp, B.J.; Puchalski, T.A.; Balkwill, F.; et al. A first-in-human, first-in-class, phase I study of carlumab (CNTO 888), a human monoclonal antibody against CC-chemokine ligand 2 in patients with solid tumors. Cancer Chemother. Pharmacol. 2013, 71, 1041-1050. [CrossRef] 
103. Nywening, T.M.; Wang-Gillam, A.; Sanford, D.E.; Belt, B.A.; Panni, R.Z.; Cusworth, B.M.; Toriola, A.T.; Nieman, R.K.; Worley, L.A.; Yano, M.; et al. Targeting tumour-associated macrophages with CCR2 inhibition in combination with FOLFIRINOX in patients with borderline resectable and locally advanced pancreatic cancer: A single-centre, open-label, dose-finding, non-randomised, phase $1 \mathrm{~b}$ trial. Lancet Oncol. 2016, 17, 651-662. [CrossRef]

104. Gordon, S.R.; Maute, R.L.; Dulken, B.W.; Hutter, G.; George, B.M.; McCracken, M.N.; Gupta, R.; Tsai, J.M.; Sinha, R.; Corey, D.; et al. PD-1 expression by tumour-associated macrophages inhibits phagocytosis and tumour immunity. Nature 2017, 545, 495-499. [CrossRef]

105. Li, C.W.; Lai, Y.J.; Hsu, J.L.; Hung, M.C. Activation of phagocytosis by immune checkpoint blockade. Front. Med. 2018, 12, 473-480. [CrossRef]

106. Mayoux, M.; Roller, A.; Pulko, V.; Sammicheli, S.; Chen, S.; Sum, E.; Jost, C.; Fransen, M.F.; Buser, R.B.; Kowanetz, M.; et al. Dendritic cells dictate responses to PD-L1 blockade cancer immunotherapy. Sci. Transl. Med. 2020, 12, 473-480. [CrossRef]

107. Wilgenhof, S.; Corthals, J.; Heirman, C.; van Baren, N.; Lucas, S.; Kvistborg, P.; Thielemans, K.; Neyns, B. Phase II Study of Autologous Monocyte-Derived mRNA Electroporated Dendritic Cells (TriMixDC-MEL) Plus Ipilimumab in Patients With Pretreated Advanced Melanoma. J. Clin. Oncol. 2016, 34, 1330-1338. [CrossRef]

108. Dietrich, J.; Nakajima, H.; Colonna, M. Human inhibitory and activating Ig-like receptors which modulate the function of myeloid cells. Microbes Infect. 2000, 2, 323-329. [CrossRef]

109. Bosco, M.C.; Puppo, M.; Santangelo, C.; Anfosso, L.; Pfeffer, U.; Fardin, P.; Battaglia, F.; Varesio, L. Hypoxia modifies the transcriptome of primary human monocytes: Modulation of novel immune-related genes and identification of CC-chemokine ligand 20 as a new hypoxia-inducible gene. J. Immunol. 2006, 177, 1941-1955. [CrossRef]

110. Bosco, M.C.; Pierobon, D.; Blengio, F.; Raggi, F.; Vanni, C.; Gattorno, M.; Eva, A.; Novelli, F.; Cappello, P.; Giovarelli, M.; et al. Hypoxia modulates the gene expression profile of immunoregulatory receptors in human mature dendritic cells: Identification of TREM-1 as a novel hypoxic marker in vitro and in vivo. Blood 2011, 117, 2625-2639. [CrossRef]

111. Pierobon, D.; Bosco, M.C.; Blengio, F.; Raggi, F.; Eva, A.; Filippi, M.; Musso, T.; Novelli, F.; Cappello, P.; Varesio, L.; et al. Chronic hypoxia reprograms human immature dendritic cells by inducing a proinflammatory phenotype and TREM-1 expression. Eur. J. Immunol. 2013, 43, 949-966. [CrossRef]

112. Clark, G.J.; Ju, X.; Tate, C.; Hart, D.N. The CD300 family of molecules are evolutionarily significant regulators of leukocyte functions. Trends Immunol. 2009, 30, 209-217. [CrossRef]

113. Kanazawa, N. Dendritic cell immunoreceptors: C-type lectin receptors for pattern-recognition and signaling on antigen-presenting cells. J. Dermatol. Sci. 2007, 45, 77-86. [CrossRef]

114. Kumar, H.; Kawai, T.; Akira, S. Pathogen recognition by the innate immune system. Int. Rev. Immunol. 2011, 30, 16-34. [CrossRef]

115. Melillo, G.; Cox, G.; Biragyn, A.; Sheffler, L.; Varesio, L. Regulation of nitric oxide synthase mRNA expression by interferon-gamma and picolinic acid. J. Biol. Chem. 1994, 269, 8128.

116. Arredouani, M.S.; Palecanda, A.; Koziel, H.; Huang, Y.C.; Imrich, A.; Sulahian, T.H.; Ning, Y.Y.; Yang, Z.; Pikkarainen, T.; Sankala, M.; et al. MARCO is the major binding receptor for unopsonized particles and bacteria on human alveolar macrophages. J. Immunol. 2005, 175, 6058-6064. [CrossRef]

117. Nakamura, K.; Funakoshi, H.; Miyamoto, K.; Tokunaga, F.; Nakamura, T. Molecular cloning and functional characterization of a human scavenger receptor with C-type lectin (SRCL), a novel member of a scavenger receptor family. Biochem. Biophys. Res. Commun. 2001, 280, 1028-1035. [CrossRef]

118. Pasare, C.; Medzhitov, R. Toll-like receptors: Linking innate and adaptive immunity. Adv. Exp. Med. Biol. 2005, 560, 11-18.

119. Akira, S.; Takeda, K.; Kaisho, T. Toll-like receptors: Critical proteins linking innate and acquired immunity. Nat. Immunol. 2001, 2, 675-680. [CrossRef]

120. Kawai, T.; Akira, S. The role of pattern-recognition receptors in innate immunity: Update on Toll-like receptors. Nat. Immunol. 2010, 11, 373-384. [CrossRef]

121. Wenink, M.H.; van den Berg, W.B.; van Riel, P.L.; Radstake, T.R. Fc gamma receptor mediated modulation of dendritic cells as a potential strategy in the battle against rheumatoid arthritis. Neth. J. Med. 2006, 64, 103-108. 
122. Javaid, N.; Choi, S. Toll-like Receptors from the Perspective of Cancer Treatment. Cancers 2020, $12,297$. [CrossRef] [PubMed]

123. Georgoudaki, A.M.; Prokopec, K.E.; Boura, V.F.; Hellqvist, E.; Sohn, S.; Ostling, J.; Dahan, R.; Harris, R.A.; Rantalainen, M.; Klevebring, D.; et al. Reprogramming Tumor-Associated Macrophages by Antibody Targeting Inhibits Cancer Progression and Metastasis. Cell Rep. 2016, 15, 2000-2011. [CrossRef] [PubMed]

124. La, F.L.; Boura, V.F.; Alexeyenko, A.; Berglund, A.; Ponten, V.; Mattsson, J.S.M.; Djureinovic, D.; Persson, J.; Brunnstrom, H.; Isaksson, J.; et al. Expression of scavenger receptor MARCO defines a targetable tumor-associated macrophage subset in non-small cell lung cancer. Int. J. Cancer 2018, 143, 1741-1752.

125. LeMaoult, J.; Zafaranloo, K.; Le Danff, C.; Carosella, E.D. HLA-G up-regulates ILT2, ILT3, ILT4, and KIR2DL4 in antigen presenting cells, NK cells, and T cells. FASEB J. 2005, 19, 662-664. [CrossRef]

126. Weiskopf, K. Cancer immunotherapy targeting the CD47/SIRPalpha axis. Eur. J. Cancer 2017, 76, $100-109$. [CrossRef]

127. Willingham, S.B.; Volkmer, J.P.; Gentles, A.J.; Sahoo, D.; Dalerba, P.; Mitra, S.S.; Wang, J.; Contreras-Trujillo, H.; Martin, R.; Cohen, J.D.; et al. The CD47-signal regulatory protein alpha (SIRPa) interaction is a therapeutic target for human solid tumors. Proc. Natl. Acad. Sci. USA 2012, 109, 6662-6667. [CrossRef]

128. Curiel, T.J.; Wei, S.; Dong, H.; Alvarez, X.; Cheng, P.; Mottram, P.; Krzysiek, R.; Knutson, K.L.; Daniel, B.; Zimmermann, M.C.; et al. Blockade of B7-H1 improves myeloid dendritic cell-mediated antitumor immunity. Nat. Med. 2003, 9, 562-567. [CrossRef]

129. Han, G.; Chen, G.; Shen, B.; Li, Y. Tim-3: An activation marker and activation limiter of innate immune cells. Front. Immunol. 2013, 4, 449. [CrossRef]

130. Chiba, S.; Baghdadi, M.; Akiba, H.; Yoshiyama, H.; Kinoshita, I.; Dosaka-Akita, H.; Fujioka, Y.; Ohba, Y.; Gorman, J.V.; Colgan, J.D.; et al. Tumor-infiltrating DCs suppress nucleic acid-mediated innate immune responses through interactions between the receptor TIM-3 and the alarmin HMGB1. Nat. Immunol. 2012, 13, 832-842. [CrossRef]

131. Fang, H.Y.; Hughes, R.; Murdoch, C.; Coffelt, S.B.; Biswas, S.K.; Harris, A.L.; Johnson, R.S.; Imityaz, H.Z.; Simon, M.C.; Fredlund, E.; et al. Hypoxia-inducible factors 1 and 2 are important transcriptional effectors in primary macrophages experiencing hypoxia. Blood 2009, 114, 844-859. [CrossRef]

132. Yang, M.; Ma, C.; Liu, S.; Sun, J.; Shao, Q.; Gao, W.; Zhang, Y.; Li, Z.; Xie, Q.; Dong, Z.; et al. Hypoxia skews dendritic cells to a $\mathrm{T}$ helper type 2-stimulating phenotype and promotes tumour cell migration by dendritic cell-derived osteopontin. Immunology 2009, 128, e237-e249. [CrossRef] [PubMed]

133. Raggi, F.; Blengio, F.; Eva, A.; Pende, D.; Varesio, L.; Bosco, M.C. Identification of CD300a as a new hypoxia-inducible gene and a regulator of CCL20 and VEGF production by human monocytes and macrophages. Innate Immun. 2014, 20, 721-734. [CrossRef] [PubMed]

134. Kuhlicke, J.; Frick, J.S.; Morote-Garcia, J.C.; Rosenberger, P.; Eltzschig, H.K. Hypoxia inducible factor (HIF)-1 coordinates induction of Toll-like receptors TLR2 and TLR6 during hypoxia. PLoS ONE 2007, 2, e1364. [CrossRef] [PubMed]

135. Khalil, M.; Vonderheide, R.H. Anti-CD40 agonist antibodies: Preclinical and clinical experience. Update Cancer Ther. 2007, 2, 61-65. [CrossRef]

136. Beatty, G.L.; Chiorean, E.G.; Fishman, M.P.; Saboury, B.; Teitelbaum, U.R.; Sun, W.; Huhn, R.D.; Song, W.; Li, D.; Sharp, L.L.; et al. CD40 agonists alter tumor stroma and show efficacy against pancreatic carcinoma in mice and humans. Science 2011, 331, 1612-1616. [CrossRef]

137. Perry, C.J.; Munoz-Rojas, A.R.; Meeth, K.M.; Kellman, L.N.; Amezquita, R.A.; Thakral, D.; Du, V.Y.; Wang, J.X.; Damsky, W.; Kuhlmann, A.L.; et al. Myeloid-targeted immunotherapies act in synergy to induce inflammation and antitumor immunity. J. Exp. Med. 2018, 215, 877-893. [CrossRef]

138. Hoves, S.; Ooi, C.H.; Wolter, C.; Sade, H.; Bissinger, S.; Schmittnaegel, M.; Ast, O.; Giusti, A.M.; Wartha, K.; Runza, V.; et al. Rapid activation of tumor-associated macrophages boosts preexisting tumor immunity. J. Exp. Med. 2018, 215, 859-876. [CrossRef]

139. Li, F.; Ravetch, J.V. Inhibitory Fcgamma receptor engagement drives adjuvant and anti-tumor activities of agonistic CD40 antibodies. Science 2011, 333, 1030-1034. [CrossRef]

140. Beatty, G.L.; Torigian, D.A.; Chiorean, E.G.; Saboury, B.; Brothers, A.; Alavi, A.; Troxel, A.B.; Sun, W.; Teitelbaum, U.R.; Vonderheide, R.H.; et al. A phase I study of an agonist CD40 monoclonal antibody (CP-870,893) in combination with gemcitabine in patients with advanced pancreatic ductal adenocarcinoma. Clin. Cancer Res. 2013, 19, 6286-6295. [CrossRef] 
141. Chao, M.P.; Alizadeh, A.A.; Tang, C.; Myklebust, J.H.; Varghese, B.; Gill, S.; Jan, M.; Cha, A.C.; Chan, C.K.; Tan, B.T.; et al. Anti-CD47 antibody synergizes with rituximab to promote phagocytosis and eradicate non-Hodgkin lymphoma. Cell 2010, 142, 699-713. [CrossRef]

142. Ring, N.G.; Herndler-Brandstetter, D.; Weiskopf, K.; Shan, L.; Volkmer, J.P.; George, B.M.; Lietzenmayer, M.; McKenna, K.M.; Naik, T.J.; McCarty, A.; et al. Anti-SIRPalpha antibody immunotherapy enhances neutrophil and macrophage antitumor activity. Proc. Natl. Acad. Sci. USA 2017, 114, E10578-E10585. [CrossRef] [PubMed]

143. Sikic, B.I.; Lakhani, N.; Patnaik, A.; Shah, S.A.; Chandana, S.R.; Rasco, D.; Colevas, A.D.; O'Rourke, T.; Narayanan, S.; Papadopoulos, K.; et al. First-in-Human, First-in-Class Phase I Trial of the Anti-CD47 Antibody Hu5F9-G4 in Patients With Advanced Cancers. J. Clin. Oncol. 2019, 37, 946-953. [CrossRef] [PubMed]

144. Barkal, A.A.; Weiskopf, K.; Kao, K.S.; Gordon, S.R.; Rosental, B.; Yiu, Y.Y.; George, B.M.; Markovic, M.; Ring, N.G.; Tsai, J.M.; et al. Engagement of MHC class I by the inhibitory receptor LILRB1 suppresses macrophages and is a target of cancer immunotherapy. Nat. Immunol. 2018, 19, 76-84. [CrossRef] [PubMed]

145. Gubin, M.M.; Esaulova, E.; Ward, J.P.; Malkova, O.N.; Runci, D.; Wong, P.; Noguchi, T.; Arthur, C.D.; Meng, W.; Alspach, E.; et al. High-Dimensional Analysis Delineates Myeloid and Lymphoid Compartment Remodeling during Successful Immune-Checkpoint Cancer Therapy. Cell 2018, 175, 1443. [CrossRef] [PubMed]

146. Rodell, C.B.; Arlauckas, S.P.; Cuccarese, M.F.; Garris, C.S.; Li, R.; Ahmed, M.S.; Kohler, R.H.; Pittet, M.J.; Weissleder, R. TLR7/8-agonist-loaded nanoparticles promote the polarization of tumour-associated macrophages to enhance cancer immunotherapy. Nat. Biomed. Eng 2018, 2, 578-588. [CrossRef] [PubMed]

147. Kaczanowska, S.; Joseph, A.M.; Davila, E. TLR agonists: Our best frenemy in cancer immunotherapy. J. Leukoc. Biol. 2013, 93, 847-863. [CrossRef]

148. Vidyarthi, A.; Khan, N.; Agnihotri, T.; Negi, S.; Das, D.K.; Aqdas, M.; Chatterjee, D.; Colegio, O.R.; Tewari, M.K.; Agrewala, J.N. TLR-3 Stimulation Skews M2 Macrophages to M1 Through IFN-alphabeta Signaling and Restricts Tumor Progression. Front. Immunol. 2018, 9, 1650. [CrossRef]

149. Sato-Kaneko, F.; Yao, S.; Ahmadi, A.; Zhang, S.S.; Hosoya, T.; Kaneda, M.M.; Varner, J.A.; Pu, M.; Messer, K.S.; Guiducci, C.; et al. Combination immunotherapy with TLR agonists and checkpoint inhibitors suppresses head and neck cancer. JCI Insight 2017, 2, e93397. [CrossRef]

150. Solinas, C.; De Silva, P.; Bron, D.; Willard-Gallo, K.; Sangiolo, D. Significance of TIM3 expression in cancer: From biology to the clinic. Semin. Oncol. 2019, 46, 372-379. [CrossRef]

151. Scarlett, U.K.; Cubillos-Ruiz, J.R.; Nesbeth, Y.C.; Martinez, D.G.; Engle, X.; Gewirtz, A.T.; Ahonen, C.L.; Conejo-Garcia, J.R. In situ stimulation of CD40 and Toll-like receptor 3 transforms ovarian cancer-infiltrating dendritic cells from immunosuppressive to immunostimulatory cells. Cancer Res. 2009, 69, 7329-7337. [CrossRef]

152. Colonna, M. TREMs in the immune system and beyond. Nat. Rev. Immunol. 2003, 3, 445-453. [CrossRef] [PubMed]

153. Ford, J.W.; McVicar, D.W. TREM and TREM-like receptors in inflammation and disease. Curr. Opin. Immunol. 2009, 21, 38-46. [CrossRef] [PubMed]

154. Sharif, O.; Knapp, S. From expression to signaling: Roles of TREM-1 and TREM-2 in innate immunity and bacterial infection. Immunobiology 2008, 213, 701-713. [CrossRef] [PubMed]

155. Gingras, M.C.; Lapillonne, H.; Margolin, J.F. TREM-1, MDL-1, and DAP12 expression is associated with a mature stage of myeloid development. Mol. Immunol. 2002, 38, 817-824. [CrossRef]

156. Tessarz, A.S.; Cerwenka, A. The TREM-1/DAP12 pathway. Immunol. Lett. 2008, 116, 111-116. [CrossRef]

157. Pelham, C.J.; Pandya, A.N.; Agrawal, D.K. Triggering receptor expressed on myeloid cells receptor family modulators: A patent review. Expert Opin. Ther. Pat. 2014, 24, 1383-1395. [CrossRef]

158. Allcock, R.J.; Barrow, A.D.; Forbes, S.; Beck, S.; Trowsdale, J. The human TREM gene cluster at 6p21.1 encodes both activating and inhibitory single IgV domain receptors and includes NKp44. Eur. J. Immunol. 2003, 33, 567-577. [CrossRef]

159. Chung, D.H.; Seaman, W.E.; Daws, M.R. Characterization of TREM-3, an activating receptor on mouse macrophages: Definition of a family of single Ig domain receptors on mouse chromosome 17. Eur. J. Immunol. 2002, 32, 59-66. [CrossRef]

160. Nguyen, A.H.; Berim, I.G.; Agrawal, D.K. Chronic inflammation and cancer: Emerging roles of triggering receptors expressed on myeloid cells. Expert. Rev. Clin. Immunol. 2015, 11, 849-857. [CrossRef] 
161. Colonna, M.; Facchetti, F. TREM-1 (triggering receptor expressed on myeloid cells): A new player in acute inflammatory responses. J. Infect. Dis. 2003, 187 (Suppl. S2), S397-S401. [CrossRef]

162. Bouchon, A.; Facchetti, F.; Weigand, M.A.; Colonna, M. TREM-1 amplifies inflammation and is a crucial mediator of septic shock. Nature 2001, 410, 1103-1107. [CrossRef] [PubMed]

163. Radaev, S.; Kattah, M.; Rostro, B.; Colonna, M.; Sun, P.D. Crystal structure of the human myeloid cell activating receptor TREM-1. Structure 2003, 11, 1527-1535. [CrossRef] [PubMed]

164. Kelker, M.S.; Foss, T.R.; Peti, W.; Teyton, L.; Kelly, J.W.; Wuthrich, K.; Wilson, I.A. Crystal structure of human triggering receptor expressed on myeloid cells 1 (TREM-1) at 1.47 A. J. Mol. Biol. 2004, 342, 1237-1248. [CrossRef] [PubMed]

165. Kelker, M.S.; Debler, E.W.; Wilson, I.A. Crystal structure of mouse triggering receptor expressed on myeloid cells 1 (TREM-1) at 1.76 A. J. Mol. Biol. 2004, 344, 1175-1181. [CrossRef]

166. Baruah, S.; Keck, K.; Vrenios, M.; Pope, M.R.; Pearl, M.; Doerschug, K.; Klesney-Tait, J. Identification of a Novel Splice Variant Isoform of TREM-1 in Human Neutrophil Granules. J. Immunol. 2015, 195, 5725-5731. [CrossRef]

167. Gomez-Pina, V.; Soares-Schanoski, A.; Rodriguez-Rojas, A.; Del Fresno, C.; Garcia, F.; Vallejo-Cremades, M.T.; Fernandez-Ruiz, I.; Arnalich, F.; Fuentes-Prior, P.; Lopez-Collazo, E. Metalloproteinases shed TREM-1 ectodomain from lipopolysaccharide-stimulated human monocytes. J. Immunol. 2007, 179, 4065-4073. [CrossRef]

168. Gibot, S.; Kolopp-Sarda, M.N.; Bene, M.C.; Bollaert, P.E.; Lozniewski, A.; Mory, F.; Levy, B.; Faure, G.C. A soluble form of the triggering receptor expressed on myeloid cells-1 modulates the inflammatory response in murine sepsis. J. Exp. Med. 2004, 200, 1419-1426. [CrossRef]

169. Haselmayer, P.; Grosse-Hovest, L.; von Landenberg, P.; Schild, H.; Radsak, M.P. TREM-1 ligand expression on platelets enhances neutrophil activation. Blood 2007, 110, 1029-1035. [CrossRef]

170. Dorner, B.G.; Scheffold, A.; Rolph, M.S.; Huser, M.B.; Kaufmann, S.H.; Radbruch, A.; Flesch, I.E.; Kroczek, R.A. MIP-1alpha, MIP-1beta, RANTES, and ATAC/lymphotactin function together with IFN-gamma as type 1 cytokines. Proc. Natl. Acad. Sci. USA 2002, 99, 6181-6186. [CrossRef]

171. Bleharski, J.R.; Kiessler, V.; Buonsanti, C.; Sieling, P.A.; Stenger, S.; Colonna, M.; Modlin, R.L. A role for triggering receptor expressed on myeloid cells-1 in host defense during the early-induced and adaptive phases of the immune response. J. Immunol. 2003, 170, 3812-3818. [CrossRef]

172. Fortin, C.F.; Lesur, O.; Fulop, T., Jr. Effects of TREM-1 activation in human neutrophils: Activation of signaling pathways, recruitment into lipid rafts and association with TLR4. Int. Immunol. 2007, 19, 41-50. [CrossRef] [PubMed]

173. Radsak, M.P.; Salih, H.R.; Rammensee, H.G.; Schild, H. Triggering receptor expressed on myeloid cells-1 in neutrophil inflammatory responses: Differential regulation of activation and survival. J. Immunol. 2004, 172, 4956-4963. [CrossRef] [PubMed]

174. Zheng, H.; Heiderscheidt, C.A.; Joo, M.; Gao, X.; Knezevic, N.; Mehta, D.; Sadikot, R.T. MYD88-dependent and -independent activation of TREM-1 via specific TLR ligands. Eur. J. Immunol. 2010, 40, 162-171. [CrossRef] [PubMed]

175. Netea, M.G.; Azam, T.; Ferwerda, G.; Girardin, S.E.; Kim, S.H.; Dinarello, C.A. Triggering receptor expressed on myeloid cells-1 (TREM-1) amplifies the signals induced by the NACHT-LRR (NLR) pattern recognition receptors. J. Leukoc. Biol. 2006, 80, 1454-1461. [CrossRef]

176. Rolli, J.; Loukili, N.; Levrand, S.; Rosenblatt-Velin, N.; Rignault-Clerc, S.; Waeber, B.; Feihl, F.; Pacher, P.; Liaudet, L. Bacterial flagellin elicits widespread innate immune defense mechanisms, apoptotic signaling, and a sepsis-like systemic inflammatory response in mice. Crit. Care 2010, 14, R160. [CrossRef]

177. Molad, Y.; Pokroy-Shapira, E.; Carmon, V. CpG-oligodeoxynucleotide-induced TLR9 activation regulates macrophage TREM-1 expression and shedding. Innate Immun. 2013, 19, 623-630. [CrossRef]

178. Derive, M.; Massin, F.; Gibot, S. Triggering receptor expressed on myeloid cells-1 as a new therapeutic target during inflammatory diseases. Self/Nonself 2010, 1, 225-230. [CrossRef]

179. Arts, R.J.; Joosten, L.A.; van der Meer, J.W.; Netea, M.G. TREM-1: Intracellular signaling pathways and interaction with pattern recognition receptors. J. Leukoc. Biol. 2013, 93, 209-215. [CrossRef]

180. Roe, K.; Gibot, S.; Verma, S. Triggering receptor expressed on myeloid cells-1 (TREM-1): A new player in antiviral immunity? Front. Microbiol. 2014, 5, 627. [CrossRef] 
181. Hyun, J.; McMahon, R.S.; Lang, A.L.; Edwards, J.S.; Badilla, A.D.; Greene, M.E.; Stone, G.W.; Pallikkuth, S.; Stevenson, M.; Dykxhoorn, D.M.; et al. HIV and HCV augments inflammatory responses through increased TREM-1 expression and signaling in Kupffer and Myeloid cells. PLoS Pathog. 2019, 15, e1007883. [CrossRef]

182. Zanzinger, K.; Schellack, C.; Nausch, N.; Cerwenka, A. Regulation of triggering receptor expressed on myeloid cells 1 expression on mouse inflammatory monocytes. Immunology 2009, 128, 185-195. [CrossRef] [PubMed]

183. Zeng, H.; Ornatowska, M.; Joo, M.S.; Sadikot, R.T. TREM-1 expression in macrophages is regulated at transcriptional level by NF-kappaB and PU.1. Eur. J. Immunol. 2007, 37, 2300-2308. [CrossRef] [PubMed]

184. Gibot, S.; Buonsanti, C.; Massin, F.; Romano, M.; Kolopp-Sarda, M.N.; Benigni, F.; Faure, G.C.; Bene, M.C.; Panina-Bordignon, P.; Passini, N.; et al. Modulation of the triggering receptor expressed on the myeloid cell type 1 pathway in murine septic shock. Infect. Immun. 2006, 74, 2823-2830. [CrossRef] [PubMed]

185. Wu, M.; Peng, A.; Sun, M.; Deng, Q.; Hazlett, L.D.; Yuan, J.; Liu, X.; Gao, Q.; Feng, L.; He, J.; et al. TREM-1 amplifies corneal inflammation after Pseudomonas aeruginosa infection by modulating Toll-like receptor signaling and Th1/Th2-type immune responses. Infect. Immun. 2011, 79, 2709-2716. [CrossRef]

186. Gibot, S.; Alauzet, C.; Massin, F.; Sennoune, N.; Faure, G.C.; Bene, M.C.; Lozniewski, A.; Bollaert, P.E.; Levy, B. Modulation of the triggering receptor expressed on myeloid cells-1 pathway during pneumonia in rats. $J$. Infect. Dis. 2006, 194, 975-983. [CrossRef]

187. Buckland, K.F.; Ramaprakash, H.; Murray, L.A.; Carpenter, K.J.; Choi, E.S.; Kunkel, S.L.; Lukacs, N.W.; Xing, Z.; Aoki, N.; Hartl, D.; et al. Triggering receptor expressed on myeloid cells-1 (TREM-1) modulates immune responses to Aspergillus fumigatus during fungal asthma in mice. Immunol. Investig. 2011, 40, 692-722. [CrossRef]

188. Hu, L.T.; Du, Z.D.; Zhao, G.Q.; Jiang, N.; Lin, J.; Wang, Q.; Xu, Q.; Cong, L.; Qiu, S. Role of TREM-1 in response to Aspergillus fumigatus infection in corneal epithelial cells. Int. Immunopharmacol. 2014, 23, 288-293. [CrossRef]

189. DePaula-Silva, A.B.; Gorbea, C.; Doty, D.J.; Libbey, J.E.; Sanchez, J.M.S.; Hanak, T.J.; Cazalla, D.; Fujinami, R.S. Differential transcriptional profiles identify microglial- and macrophage-specific gene markers expressed during virus-induced neuroinflammation. J. Neuroinflamm. 2019, 16, 152. [CrossRef]

190. Gibot, S.; Cravoisy, A.; Levy, B.; Bene, M.C.; Faure, G.; Bollaert, P.E. Soluble triggering receptor expressed on myeloid cells and the diagnosis of pneumonia. N. Engl. J. Med. 2004, 350, 451-458. [CrossRef]

191. Lagler, H.; Sharif, O.; Haslinger, I.; Matt, U.; Stich, K.; Furtner, T.; Doninger, B.; Schmid, K.; Gattringer, R.; de Vos, A.F.; et al. TREM-1 activation alters the dynamics of pulmonary IRAK-M expression in vivo and improves host defense during pneumococcal pneumonia. J. Immunol. 2009, 183, 2027-2036. [CrossRef]

192. de Oliveira, M.A.; Dos Santos Dantas, P.H.; Figueira, M.S.-S.; Sales-Campos, H. The role of the triggering receptor expressed on myeloid cells-1 (TREM-1) in non-bacterial infections. Crit. Rev. Microbiol. 2020, 1-16. [CrossRef] [PubMed]

193. Schenk, M.; Bouchon, A.; Birrer, S.; Colonna, M.; Mueller, C. Macrophages expressing triggering receptor expressed on myeloid cells-1 are underrepresented in the human intestine. J. Immunol. 2005, 174, 517-524. [CrossRef] [PubMed]

194. Yuan, Z.; Mehta, H.J.; Mohammed, K.; Nasreen, N.; Roman, R.; Brantly, M.; Sadikot, R.T. TREM-1 is induced in tumor associated macrophages by cyclo-oxygenase pathway in human non-small cell lung cancer. PLoS ONE 2014, 9, e94241. [CrossRef] [PubMed]

195. Murakami, Y.; Kohsaka,H.; Kitasato, H.; Akahoshi, T. Lipopolysaccharide-induced up-regulation of triggering receptor expressed on myeloid cells-1 expression on macrophages is regulated by endogenous prostaglandin E2. J. Immunol. 2007, 178, 1144-1150. [CrossRef]

196. Hosoda, H.; Tamura, H.; Kida, S.; Nagaoka, I. Transcriptional regulation of mouse TREM-1 gene in RAW264.7 macrophage-like cells. Life Sci. 2011, 89, 115-122. [CrossRef]

197. Syed, M.A.; Joo, M.; Abbas, Z.; Rodger, D.; Christman, J.W.; Mehta, D.; Sadikot, R.T. Expression of TREM-1 is inhibited by PGD2 and PGJ2 in macrophages. Exp. Cell Res. 2010, 316, 3140-3149. [CrossRef]

198. Hosoda, H.; Tamura, H.; Nagaoka, I. Evaluation of the lipopolysaccharide-induced transcription of the human TREM-1 gene in vitamin D3-matured THP-1 macrophage-like cells. Int. J. Mol. Med. 2015, 36, 1300-1310. [CrossRef]

199. Kim, T.H.; Lee, B.; Kwon, E.; Choi, S.J.; Lee, Y.H.; Song, G.G.; Sohn, J.; Ji, J.D. Regulation of TREM-1 expression by 1,25-dihydroxyvitamin D3 in human monocytes/macrophages. Immunol. Lett. 2013, 154, 80-85. [CrossRef] 
200. Rigo, I.; McMahon, L.; Dhawan, P.; Christakos, S.; Yim, S.; Ryan, L.K.; Diamond, G. Induction of triggering receptor expressed on myeloid cells (TREM-1) in airway epithelial cells by $1,25(\mathrm{OH})(2)$ vitamin $\mathrm{D}(3)$. Innate Immun. 2012, 18, 250-257. [CrossRef]

201. Pierobon, D.; Raggi, F.; Cambieri, I.; Pelassa, S.; Occhipinti, S.; Cappello, P.; Novelli, F.; Musso, T.; Eva, A.; Castagnoli, C.; et al. Regulation of Langerhans cell functions in a hypoxic environment. J. Mol. Med. 2016, 94, 943-955. [CrossRef]

202. Murat, A.; Migliavacca, E.; Hussain, S.F.; Heimberger, A.B.; Desbaillets, I.; Hamou, M.F.; Ruegg, C.; Stupp, R.; Delorenzi, M.; Hegi, M.E. Modulation of angiogenic and inflammatory response in glioblastoma by hypoxia. PLoS ONE 2009, 4, e5947. [CrossRef] [PubMed]

203. Wenger, R.H.; Stiehl, D.P.; Camenisch, G. Integration of oxygen signaling at the consensus HRE. Sci. STKE 2005, 2005, re12. [CrossRef] [PubMed]

204. Rankin, E.B.; Giaccia, A.J. Hypoxic control of metastasis. Science 2016, 352, 175-180. [CrossRef] [PubMed]

205. Wu, Q.; Zhou, W.; Yin, S.; Zhou, Y.; Chen, T.; Qian, J.; Su, R.; Hong, L.; Lu, H.; Zhang, F.; et al. Blocking Triggering Receptor Expressed on Myeloid Cells-1-Positive Tumor-Associated Macrophages Induced by Hypoxia Reverses Immunosuppression and Anti-Programmed Cell Death Ligand 1 Resistance in Liver Cancer. Hepatology 2019, 70, 198-214. [CrossRef]

206. Wong-Baeza, I.; Gonzalez-Roldan, N.; Ferat-Osorio, E.; Esquivel-Callejas, N.; Aduna-Vicente, R.; Arriaga-Pizano, L.; Astudillo-de la Vega, H.; Villasis-Keever, M.A.; Torres-Gonzalez, R.; Estrada-Garcia, I.; et al. Triggering receptor expressed on myeloid cells (TREM-1) is regulated post-transcriptionally and its ligand is present in the sera of some septic patients. Clin. Exp. Immunol. 2006, 145, 448-455. [CrossRef]

207. El Mezayen, R.; El Gazzar, M.; Seeds, M.C.; McCall, C.E.; Dreskin, S.C.; Nicolls, M.R. Endogenous signals released from necrotic cells augment inflammatory responses to bacterial endotoxin. Immunol. Lett. 2007, 111, 36-44. [CrossRef]

208. Wu, J.; Li, J.; Salcedo, R.; Mivechi, N.F.; Trinchieri, G.; Horuzsko, A. The proinflammatory myeloid cell receptor TREM-1 controls Kupffer cell activation and development of hepatocellular carcinoma. Cancer Res. 2012, 72, 3977-3986. [CrossRef]

209. Read, C.B.; Kuijper, J.L.; Hjorth, S.A.; Heipel, M.D.; Tang, X.; Fleetwood, A.J.; Dantzler, J.L.; Grell, S.N.; Kastrup, J.; Wang, C.; et al. Cutting Edge: Identification of neutrophil PGLYRP1 as a ligand for TREM-1. J. Immunol. 2015, 194, 1417-1421. [CrossRef]

210. Mohamadzadeh, M.; Coberley, S.S.; Olinger, G.G.; Kalina, W.V.; Ruthel, G.; Fuller, C.L.; Swenson, D.L.; Pratt, W.D.; Kuhns, D.B.; Schmaljohn, A.L. Activation of triggering receptor expressed on myeloid cells-1 on human neutrophils by marburg and ebola viruses. J. Virol. 2006, 80, 7235-7244. [CrossRef]

211. Dower, K.; Ellis, D.K.; Saraf, K.; Jelinsky, S.A.; Lin, L.L. Innate immune responses to TREM-1 activation: Overlap, divergence, and positive and negative cross-talk with bacterial lipopolysaccharide. J. Immunol. 2008, 180, 3520-3534. [CrossRef]

212. Barraud, D.; Gibot, S. Triggering receptor expressed on myeloid cell 1. Crit. Care Clin. 2011, 27, $265-279$. [CrossRef] [PubMed]

213. Lemarie, J.; Barraud, D.; Gibot, S. Host response biomarkers in sepsis: Overview on sTREM-1 detection. Methods Mol. Biol. 2015, 1237, 225-239. [PubMed]

214. Derive, M.; Boufenzer, A.; Gibot, S. Attenuation of responses to endotoxin by the triggering receptor expressed on myeloid cells-1 inhibitor LR12 in nonhuman primate. Anesthesiology 2014, 120, 935-942. [CrossRef] [PubMed]

215. Derive, M.; Boufenzer, A.; Bouazza, Y.; Groubatch, F.; Alauzet, C.; Barraud, D.; Lozniewski, A.; Leroy, P.; Tran, N.; Gibot, S. Effects of a TREM-like transcript 1-derived peptide during hypodynamic septic shock in pigs. Shock 2013, 39, 176-182. [CrossRef] [PubMed]

216. Gibot, S.; Massin, F.; Marcou, M.; Taylor, V.; Stidwill, R.; Wilson, P.; Singer, M.; Bellingan, G. TREM-1 promotes survival during septic shock in mice. Eur. J. Immunol. 2007, 37, 456-466. [CrossRef]

217. Cavaillon, J.M. Monocyte TREM-1 membrane expression in non-infectious inflammation. Crit. Care 2009, 13, 152. [CrossRef]

218. Collins, C.E.; La, D.T.; Yang, H.T.; Massin, F.; Gibot, S.; Faure, G.; Stohl, W. Elevated synovial expression of triggering receptor expressed on myeloid cells 1 in patients with septic arthritis or rheumatoid arthritis. Ann. Rheum. Dis. 2009, 68, 1768-1774. [CrossRef] 
219. Kuai, J.; Gregory, B.; Hill, A.; Pittman, D.D.; Feldman, J.L.; Brown, T.; Carito, B.; O’Toole, M.; Ramsey, R.; Adolfsson, O.; et al. TREM-1 expression is increased in the synovium of rheumatoid arthritis patients and induces the expression of pro-inflammatory cytokines. Rheumatology 2009, 48, 1352-1358. [CrossRef]

220. Murakami, Y.; Akahoshi, T.; Aoki, N.; Toyomoto, M.; Miyasaka, N.; Kohsaka, H. Intervention of an inflammation amplifier, triggering receptor expressed on myeloid cells 1, for treatment of autoimmune arthritis. Arthritis Rheum. 2009, 60, 1615-1623. [CrossRef]

221. Ho, C.C.; Liao, W.Y.; Wang, C.Y.; Lu, Y.H.; Huang, H.Y.; Chen, H.Y.; Chan, W.K.; Chen, H.W.; Yang, P.C. TREM-1 expression in tumor-associated macrophages and clinical outcome in lung cancer. Am. J. Respir. Crit. Care Med. 2008, 177, 763-770. [CrossRef]

222. Kuemmel, A.; Alflen, A.; Schmidt, L.H.; Sebastian, M.; Wiewrodt, R.; Schulze, A.B.; Buhl, R.; Radsak, M. Soluble Triggering Receptor Expressed on Myeloid Cells 1 in lung cancer. Sci. Rep. 2018, 8, 10766. [CrossRef] [PubMed]

223. Fontana, R.; Raccosta, L.; Rovati, L.; Steffensen, K.R.; Paniccia, A.; Jakobsson, T.; Melloni, G.; Bandiera, A.; Mangili, G.; Bergamini, A.; et al. Nuclear receptor ligands induce TREM-1 expression on dendritic cells: Analysis of their role in tumors. Oncoimmunology 2019, 8, 1554967. [CrossRef] [PubMed]

224. Schenk, M.; Bouchon, A.; Seibold, F.; Mueller, C. TREM-1-Expressing intestinal macrophages crucially amplify chronic inflammation in experimental colitis and inflammatory bowel diseases. J. Clin. Investig. 2007, 117, 3097-3106. [CrossRef] [PubMed]

225. Park, J.J.; Cheon, J.H.; Kim, B.Y.; Kim, D.H.; Kim, E.S.; Kim, T.I.; Lee, K.R.; Kim, W.H. Correlation of serum-soluble triggering receptor expressed on myeloid cells-1 with clinical disease activity in inflammatory bowel disease. Dig. Dis. Sci. 2009, 54, 1525-1531. [CrossRef]

226. Weber, B.; Schuster, S.; Zysset, D.; Rihs, S.; Dickgreber, N.; Schurch, C.; Riether, C.; Siegrist, M.; Schneider, C.; Pawelski, H.; et al. TREM-1 deficiency can attenuate disease severity without affecting pathogen clearance. PLoS Pathog. 2014, 10, e1003900. [CrossRef]

227. Tzivras, M.; Koussoulas, V.; Giamarellos-Bourboulis, E.J.; Tzivras, D.; Tsaganos, T.; Koutoukas, P.; Giamarellou, H.; Archimandritis, A. Role of soluble triggering receptor expressed on myeloid cells in inflammatory bowel disease. World J. Gastroenterol. 2006, 12, 3416-3419. [CrossRef]

228. Maeda, S.; Kamata, H.; Luo, J.L.; Leffert, H.; Karin, M. IKKbeta couples hepatocyte death to cytokine-driven compensatory proliferation that promotes chemical hepatocarcinogenesis. Cell 2005, 121, 977-990. [CrossRef]

229. Liao, R.; Sun, T.W.; Yi, Y.; Wu, H.; Li, Y.W.; Wang, J.X.; Zhou, J.; Shi, Y.H.; Cheng, Y.F.; Qiu, S.J.; et al. Expression of TREM-1 in hepatic stellate cells and prognostic value in hepatitis B-related hepatocellular carcinoma. Cancer Sci. 2012, 103, 984-992. [CrossRef]

230. Duan, M.; Wang, Z.C.; Wang, X.Y.; Shi, J.Y.; Yang, L.X.; Ding, Z.B.; Gao, Q.; Zhou, J.; Fan, J. TREM-1, an inflammatory modulator, is expressed in hepatocellular carcinoma cells and significantly promotes tumor progression. Ann. Surg. Oncol. 2015, 22, 3121-3129. [CrossRef]

231. Jung, K.H.; Yoo, W.; Stevenson, H.L.; Deshpande, D.; Shen, H.; Gagea, M.; Yoo, S.Y.; Wang, J.; Eckols, T.K.; Bharadwaj, U.; et al. Multifunctional Effects of a Small-Molecule STAT3 Inhibitor on NASH and Hepatocellular Carcinoma in Mice. Clin. Cancer Res. 2017, 23, 5537-5546. [CrossRef]

232. Shen, Z.T.; Sigalov, A.B. Novel TREM-1 Inhibitors Attenuate Tumor Growth and Prolong Survival in Experimental Pancreatic Cancer. Mol. Pharm. 2017, 14, 4572-4582. [CrossRef] [PubMed]

233. Anaya-Prado, R.; Norzgaray-Ibarra, F.G.; Bravo-Cuellar, A.; Perez-Avila, C.E.; Schadegg-Pena, D.; Anaya-Fernandez, M.M. [Expression of TREM-1 in patients with invasive cervical cancer and precursor lesions]. Rev. Med. Inst. Mex. Seguro Soc. 2015, 53, 722-727. [PubMed]

234. Rubin, D.C.; Shaker, A.; Levin, M.S. Chronic intestinal inflammation: Inflammatory bowel disease and colitis-associated colon cancer. Front. Immunol. 2012, 3, 107. [CrossRef] [PubMed]

235. Zhou, J.; Chai, F.; Lu, G.; Hang, G.; Chen, C.; Chen, X.; Shi, J. TREM-1 inhibition attenuates inflammation and tumor within the colon. Int. Immunopharmacol. 2013, 17, 155-161. [CrossRef] [PubMed]

236. Dantas, P.H.D.S.; Matos, A.O.; da Silva, F.E.; Silva-Sales, M.; Sales-Campos, H. Triggering receptor expressed on myeloid cells-1 (TREM-1) as a therapeutic target in infectious and noninfectious disease: A critical review. Int. Rev. Immunol. 2020, 1-15. [CrossRef] [PubMed]

237. Sigalov, A.B. A novel ligand-independent peptide inhibitor of TREM-1 suppresses tumor growth in human lung cancer xenografts and prolongs survival of mice with lipopolysaccharide-induced septic shock. Int. Immunopharmacol. 2014, 21, 208-219. [CrossRef] 
238. Derive, M.; Bouazza, Y.; Sennoun, N.; Marchionni, S.; Quigley, L.; Washington, V.; Massin, F.; Max, J.P.; Ford, J.; Alauzet, C.; et al. Soluble TREM-like transcript-1 regulates leukocyte activation and controls microbial sepsis. J. Immunol. 2012, 188, 5585-5592. [CrossRef]

239. Cuvier, V.; Lorch, U.; Witte, S.; Olivier, A.; Gibot, S.; Delor, I.; Garaud, J.J.; Derive, M.; Salcedo-Magguilli, M. A first-in-man safety and pharmacokinetics study of nangibotide, a new modulator of innate immune response through TREM-1 receptor inhibition. Br. J. Clin. Pharmacol. 2018, 84, 2270-2279. [CrossRef]

240. Horst, S.A.; Linner, A.; Beineke, A.; Lehne, S.; Holtje, C.; Hecht, A.; Norrby-Teglund, A.; Medina, E.; Goldmann, O. Prognostic value and therapeutic potential of TREM-1 in Streptococcus pyogenes- induced sepsis. J. Innate Immun. 2013, 5, 581-590. [CrossRef]

241. Wang, F.; Liu, S.; Wu, S.; Zhu, Q.; Ou, G.; Liu, C.; Wang, Y.; Liao, Y.; Sun, Z. Blocking TREM-1 signaling prolongs survival of mice with Pseudomonas aeruginosa induced sepsis. Cell Immunol. 2012, 272, 251-258. [CrossRef]

242. Hyder, L.A.; Gonzalez, J.; Harden, J.L.; Johnson-Huang, L.M.; Zaba, L.C.; Pierson, K.C.; Eungdamrong, N.J.; Lentini, T.; Gulati, N.; Fuentes-Duculan, J.; et al. TREM-1 as a potential therapeutic target in psoriasis. J. Investig. Dermatol. 2013, 133, 1742-1751. [CrossRef] [PubMed]

243. Nochi, H.; Aoki, N.; Oikawa, K.; Yanai, M.; Takiyama, Y.; Atsuta, Y.; Kobayashi, H.; Sato, K.; Tateno, M.; Matsuno, T.; et al. Modulation of hepatic granulomatous responses by transgene expression of DAP12 or TREM-1-Ig molecules. Am. J. Pathol. 2003, 162, 1191-1201. [CrossRef]

244. Zhang, G.; Liu, H.; Huang, J.; Chen, S.; Pan, X.; Huang, H.; Wang, L. TREM-1low is a novel characteristic for tumor-associated macrophages in lung cancer. Oncotarget 2016, 7, 40508-40517. [CrossRef] [PubMed]

245. Lee, Y.S.; Yeo, I.J.; Kim, K.C.; Han, S.B.; Hong, J.T. Inhibition of Lung Tumor Development in ApoE Knockout Mice via Enhancement of TREM-1 Dependent NK Cell Cytotoxicity. Front. Immunol. 2019, 10, 1379. [CrossRef] [PubMed]

246. Onnis, B.; Rapisarda, A.; Melillo, G. Development of HIF-1 Inhibitors for Cancer Therapy. J. Cell Mol. Med. 2009, 13, 2780-2786. [CrossRef] [PubMed]

247. Semenza, G.L. HIF-1 inhibitors for cancer therapy: From gene expression to drug discovery. Curr. Pharm. Des. 2009, 15, 3839-3843. [CrossRef] 